\title{
The impact of China's vehicle emissions on regional air quality in 2000 and 2020: a scenario analysis
}

\author{
E. Saikawa ${ }^{1, *}$, J. Kurokawa ${ }^{2, * *}$, M. Takigawa ${ }^{3}$, J. Borken-Kleefeld ${ }^{4}$, D. L. Mauzerall ${ }^{1}$, L. W. Horowitz ${ }^{5}$, and T. Ohara ${ }^{2}$ \\ ${ }^{1}$ Princeton University, Princeton, New Jersey, USA \\ ${ }^{2}$ National Institute for Environmental Studies, Tsukuba, Japan \\ ${ }^{3}$ Japan Agency for Marine-Earth Science and Technology, Yokohama, Japan \\ ${ }^{4}$ International Institute for Applied Systems Analysis, Laxenburg, Austria \\ ${ }^{5}$ Geophysical Fluid Dynamics Laboratory, Princeton, New Jersey, USA \\ *now at: Massachusetts Institute of Technology, Cambridge, Massachusetts, USA \\ ** now at: Japan Environmental Sanitation Center, Asia Center for Air Pollution Research, Niigata, Japan
}

Received: 5 March 2011 - Published in Atmos. Chem. Phys. Discuss.: 28 April 2011

Revised: 17 August 2011 - Accepted: 17 August 2011 - Published: 16 September 2011

\begin{abstract}
The number of vehicles in China has been increasing rapidly. We evaluate the impact of current and possible future vehicle emissions from China on Asian air quality. We modify the Regional Emission Inventory in Asia (REAS) for China's road transport sector in 2000 using updated Chinese data for the number of vehicles, annual mileage, and emission factors. We develop two scenarios for 2020: a scenario where emission factors remain the same as they were in 2000 (No-Policy, NoPol), and a scenario where Euro 3 vehicle emission standards are applied to all vehicles (except motorcycles and rural vehicles). The Euro 3 scenario is an approximation of what may be the case in 2020 as, starting in 2008, all new vehicles in China (except motorcycles) were required to meet the Euro 3 emission standards. Using the Weather Research and Forecasting model coupled with Chemistry (WRF/Chem), we examine the regional air quality response to China's vehicle emissions in 2000 and in 2020 for the NoPol and Euro 3 scenarios. We evaluate the 2000 model results with observations in Japan, China, Korea, and Russia. Under NoPol in 2020, emissions of carbon monoxide (CO), nitrogen oxides $\left(\mathrm{NO}_{\mathrm{x}}\right)$, non-methane volatile organic compounds (NMVOCs), black carbon (BC), and organic carbon (OC) from China's vehicles more than double compared to the 2000 baseline. If all vehicles meet the Euro 3 regulations in 2020, however, these emissions are reduced by more than $50 \%$ relative to NoPol. The implementation of stringent vehicle emission standards leads to a large, simultaneous reduction of the surface ozone $\left(\mathrm{O}_{3}\right)$ mixing ratios
\end{abstract}

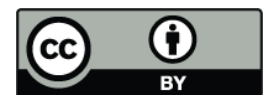

Correspondence to: E. Saikawa (esaikawa@mit.edu) and particulate matter $\left(\mathrm{PM}_{2.5}\right)$ concentrations. In the Euro 3 scenario, surface $\mathrm{O}_{3}$ is reduced by more than $10 \mathrm{ppbv}$ and surface $\mathrm{PM}_{2.5}$ is reduced by more than $10 \mu \mathrm{g} \mathrm{m}^{-3}$ relative to $\mathrm{NoPol}$ in Northeast China in all seasons. In spring, surface $\mathrm{O}_{3}$ mixing ratios and $\mathrm{PM}_{2.5}$ concentrations in neighboring countries are also reduced by more than $3 \mathrm{ppbv}$ and $1 \mu \mathrm{g} \mathrm{m}^{-3}$, respectively. We find that effective regulation of China's road transport sector will be of significant benefit for air quality both within China and across East Asia as well.

\section{Introduction}

Ozone $\left(\mathrm{O}_{3}\right)$ and aerosols influence both air quality and climate (Shindell et al., 2008, 2009; Forster et al., 2007; Unger et al., 2006; Andreae et al., 2005), as well as having adverse impacts on health (Anenberg et al., 2009; Liu et al., 2009a; Schwartz et al., 2008; Levy et al., 2001; and Dockery et al., 1993). In addition, surface $\mathrm{O}_{3}$ damages agricultural crops, resulting in reduced yields (Avnery et al., 2011; Dingenen et al., 2009, Wang and Mauzerall, 2004). Observations and modelling studies have shown a significant increase in tropospheric concentrations of these species since pre-industrial times due to anthropogenic emissions (Akimoto, 2003; Horowitz, 2006; Tsigaridis et al., 2006; Volz and Kley, 1988). Recent studies have also shown that anthropogenic emissions of ozone precursors - nitrogen oxides $\left(\mathrm{NO}_{\mathrm{x}}=\mathrm{NO}+\mathrm{NO}_{2}\right)$, non-methane volatile organic compounds (NMVOCs), carbon monoxide (CO), and methane $\left(\mathrm{CH}_{4}\right)$ - affect ozone concentrations on regional, continental, and inter-continental scales (Fiore et al., 2009; West et al.,

Published by Copernicus Publications on behalf of the European Geosciences Union. 
2009). Measurements indicate that global background $\mathrm{O}_{3}$ concentrations have approximately doubled from the late 19th to 20th centuries (Vingarzan, 2004).

An increase in the number of vehicles, first in developed countries and increasingly in developing countries such as China, is an important driver for rising $\mathrm{O}_{3}$ concentrations (Westerdahl et al., 2009). Vehicles are a significant source of all ozone precursors, except $\mathrm{CH}_{4}$. Anthropogenic $\mathrm{NO}_{\mathrm{x}}$ emissions from Asia (including East, Southeast, and South Asia) have rapidly increased from a small fraction of global emissions in the 1970s to surpass those from Europe and North America individually by the end of the 1990s (Akimoto, 2003). An analysis of tropospheric $\mathrm{NO}_{2}$ columns over China derived from the Global Ozone Monitoring Experiment (GOME) and Scanning Imaging Absorption Spectrometer for Atmospheric Cartography (SCIAMACHY) satellite instruments between 1996 and 2004 also indicates a large increase in $\mathrm{NO}_{2}$ concentrations over eastern China, especially above industrial areas (van der A et al., 2006; Richter et al., 2005). Although many countries, including developing countries, have adopted emission standards from developed countries, projected growth in the number of vehicles will have a substantial impact on the emissions and concentrations of pollutants at the local, national, regional, continental, and hemispheric scales.

China has seen explosive growth in the number of civil motor vehicles (cars, buses and trucks) since 1980. This increase in vehicles has led to substantial degradation of air quality, especially in urban areas (Cai and Xie, 2007). For example, in Beijing, vehicles accounted for 46,78 , and $83 \%$ of total emissions of the $\mathrm{NO}_{\mathrm{x}}, \mathrm{CO}$, and hydrocarbons (HC), respectively, in 1999 (Hao et al., 2006). In order to reduce vehicle emissions, China implemented the European vehicle emission standards (Euro standards) in 2001, and the standards have been regularly tightened. Table 1 illustrates the evolution of implementation of the national vehicle emission standards in China. Euro standards regulate emissions of CO, $\mathrm{HC}, \mathrm{NO}_{\mathrm{x}}$ and particulate matter (PM) with different emission limits allowed for various vehicle categories. Euro 1 is the least stringent and Euro 6 is the most stringent of existing Euro standards. China implemented Euro 3 nationally for all vehicles in 2008.

The purpose of this study is to analyze the impacts of regulating vehicle emissions in China on regional air quality. We first evaluate the influence of vehicle emissions in China on regional air quality in 2000 . Next, we use two scenarios for 2020 to investigate the influence on air quality of (1) no vehicle emission regulations; and (2) all vehicles meeting the Euro 3 emission standards. By creating two possible scenarios, we aim to estimate the benefit of full implementation and enforcement of Euro 3 emission standards, relative to no regulations, on regional air quality in 2020 .
Table 1. Implementation years and national vehicle emission standards for all sales in China.

\begin{tabular}{|c|c|c|c|c|c|c|}
\hline & Year & $\mathrm{CO}$ & $\mathrm{HC}$ & $\mathrm{HC}+\mathrm{NO}_{\mathrm{x}}$ & $\mathrm{NO}_{\mathrm{x}}$ & PM \\
\hline \multicolumn{7}{|c|}{ Light-duty gasoline $\left(\mathrm{g} \mathrm{km}^{-1}\right)$} \\
\hline Euro 1 & 2001 & 3.16 & & 1.13 & & \\
\hline Euro 2 & 2005 & 2.2 & & 0.5 & & \\
\hline Euro 3 & 2008 & 2.3 & 0.2 & & 0.15 & \\
\hline Euro 4 & 2011 & 1 & 0.1 & & 0.08 & \\
\hline Euro 5 & & 1 & 0.1 & & 0.06 & 0.005 \\
\hline Euro 6 & & 1 & 0.1 & & 0.06 & 0.005 \\
\hline \multicolumn{7}{|c|}{ Light-duty diesel $\left(\mathrm{g} \mathrm{km}^{-1}\right)$} \\
\hline Euro 1 & 2001 & 3.16 & & 1.13 & & 0.18 \\
\hline Euro 2 & 2005 & 1 & & 0.9 & & 0.1 \\
\hline Euro 3 & 2008 & 0.64 & & 0.56 & 0.5 & 0.05 \\
\hline Euro 4 & 2013 & 0.5 & & 0.3 & 0.25 & 0.025 \\
\hline Euro 5 & & 0.5 & & 0.23 & 0.18 & 0.005 \\
\hline Euro 6 & & 0.5 & & 0.17 & 0.08 & 0.005 \\
\hline \multicolumn{7}{|c|}{ Heavy-duty diesel $\left(\mathrm{g} \mathrm{kWh}^{-1}\right)$} \\
\hline Euro 1 & 2001 & 4.5 & 1.1 & & 8 & 0.612 \\
\hline Euro 2 & 2004 & 4 & 1.1 & & 7 & 0.25 \\
\hline Euro 3 & 2008 & 2.1 & 0.66 & & 5 & 0.1 \\
\hline Euro 4 & 2012 & 1.5 & 0.46 & & 3.5 & 0.02 \\
\hline Euro 5 & & 1.5 & 0.46 & & 2 & 0.02 \\
\hline Euro 6 & & 1.5 & 0.13 & & 0.4 & 0.01 \\
\hline
\end{tabular}

Note: The official implementation year of Euro 1 is 2000, but because of the complication related to the re-issuing of the standards, we consider 2001 to be the actual implementation year as is often considered in the literature.

The paper is organized as follows. Section 2 describes the development of emissions data for our scenario analyses. Section 3 explains the atmospheric chemistry models (WRF/Chem and MOZART) used in this study. Section 4 describes the scenarios and evaluates our baseline model simulation for 2000 by comparing observations with model results. In Sect. 5, we examine results from our 2020 simulations and describe the potential benefits for regional air quality of all vehicles meeting the Euro 3 vehicle emission controls in 2020. We present a summary of results and suggestions for future research in Sect. 6.

\section{Emissions}

\subsection{Emissions inventories}

In this study we combine four emissions inventories. For anthropogenic emissions, we use the Regional Emission Inventory in Asia (REAS) (Ohara et al., 2007). The REAS inventory includes anthropogenic emissions from combustion (industry, power, transport and domestic sectors including burning of fossil fuel and biofuel), industrial processes, agriculture (both soil and livestock) and others (waste treatment, emissions from aircraft and ships). Twenty-two countries 


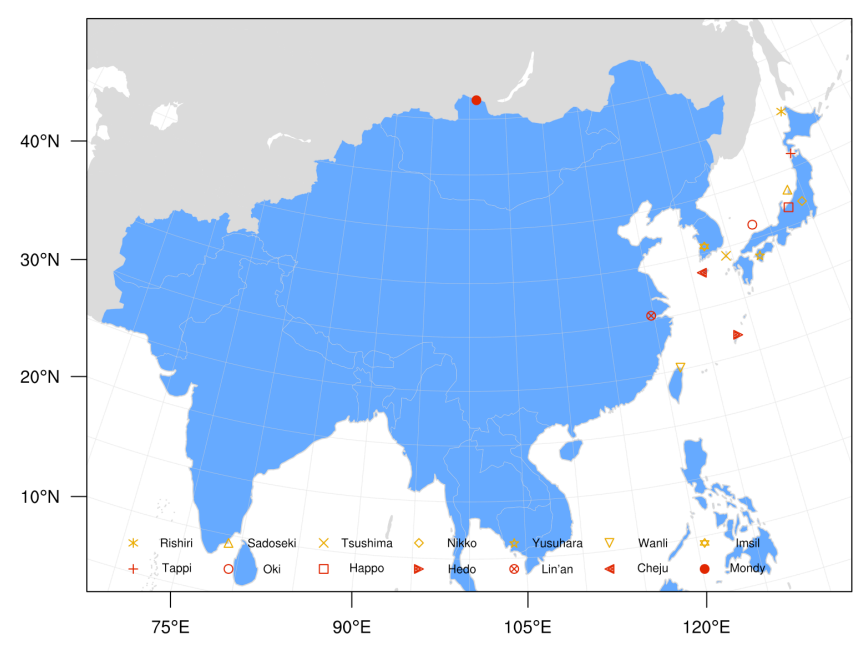

Fig. 1. WRF/Chem model domain. Blue indicates locations where the REAS emissions inventory is used. Gray indicates where the SRES A2 emissions are used. For the entire model domain, biomass burning emissions from GFED v2.1 and biogenic emissions from POET v1 are used. 14 observational sites which are used for model evaluation are also marked on the map.

are included from $10^{\circ} \mathrm{S}$ to $50^{\circ} \mathrm{N}$ latitude and from $60^{\circ} \mathrm{E}$ to $150^{\circ}$ E longitude (See Fig. 1).

REAS emissions for years 2000 and 2020 are used in this study. For 2020, REAS has three scenarios for China's emissions: Policy Failed Case (PFC), Reference (REF), and Policy Succeed Case (PSC). PFC is the worst case scenario developed, where high emissions are expected due to rapid economic growth combined with a continuation of the current energy structure with increased fossil fuel combustion and the slow adoption of new emission control technologies. The REF scenario has moderate emission rates as it assumes energy consumption to be suppressed through energy conservation, clean energy and new energy technologies as well as new emission control technologies. The PSC is an optimistic scenario where emission rates are set to be low due to the implementation of environmental policies and the fast deployment of new technologies.

The new Asian emission inventory for the NASA INTEX$\mathrm{B}$ mission suggests China's anthropogenic emissions of $\mathrm{NO}_{2}$ to be $20.8 \mathrm{Tg}$ in the year 2006 (Zhang et al., 2009). This exceeds the 2010 REAS PFC estimate of $17 \mathrm{Tg} \mathrm{NO}_{2} \mathrm{yr}^{-1}$. In addition, Klimont et al. (2009) also shows that REAS projects a moderate increase of $\mathrm{NO}_{\mathrm{x}}$ emissions for Asia, possibly resulting in underestimation even in the PFC scenario. We therefore assume that, of the REAS scenarios for 2020, the PFC scenario most closely approximates year $2020 \mathrm{NO}_{\mathrm{x}}$ emissions from China, and use it as the basis for our 2020 scenarios. China's vehicle emissions are modified as discussed in the following section.

For the target area in our study that is not covered by the REAS emissions inventory (see Fig. 1), we use other existing inventories. For anthropogenic emissions and aircraft emissions above the surface, we use the Intergovernmental Panel on Climate Change (IPCC) Special Report on Emission Scenarios (SRES) A2 emissions (IPCC, 2000) for the year 2000 and 2020. This is reasonable, as the A2 scenario also assumes continuously increasing economic growth as does the REAS PFC scenario. For all regions, we also use the year 2000 emissions from the Global Fire Emissions Database GFED v2.1 for biomass burning emissions (van der Werf et al., 2006). For biogenic emissions of $\mathrm{CO}, \mathrm{NO}_{\mathrm{x}}, \mathrm{CH}_{4}$ and NMVOCs, we use the Precursors of Ozone and their Effect on the Troposphere (POET) v1 emissions inventory (Granier et al., 2005).

\subsection{China's road transport sector emissions}

\subsubsection{Methodology}

Road transport sector emissions of $\mathrm{CO}, \mathrm{NO}_{\mathrm{x}}, \mathrm{BC}$ and $\mathrm{OC}$ in the REAS inventory were estimated by the following equation:

$E=N \times \mathrm{VMT} \times \mathrm{EF}$

$E$ : Emissions (g)

$N$ : Number of vehicles

VMT: Annual vehicle miles travelled $(\mathrm{km})$

EF: Emission factor $\left(\mathrm{g} \mathrm{km}^{-1}\right)$

In this study we modify emissions from China's road transport sector in the REAS inventory for years 2000 and 2020, using newly available data. For year 2020, we modify the PFC scenario to create two scenarios - No-Policy (NoPol) and Euro 3 regulations (Euro 3), while holding the emissions from all other sectors constant both within and outside of China.

We classify vehicles into six categories (motorcycles, private cars, light-duty vehicles, buses, trucks and rural vehicles) and two fuel types (gasoline and diesel) as listed in Table 2. $\mathrm{CO}, \mathrm{NO}_{\mathrm{x}}, \mathrm{HC}$ and $\mathrm{PM}$ are regulated by vehicle emission standards, and thus we calculate emissions for the following five chemical species $\left(\mathrm{CO}, \mathrm{NO}_{\mathrm{x}}, \mathrm{NMVOCs}, \mathrm{BC}\right.$ and $\mathrm{OC}$ ).

Two vehicle categories (motorcycles and private cars) are assumed to be all gasoline vehicles. Rural vehicles, which are the vehicles used in rural areas for passenger and freight transport, are assumed to be all diesel in China. For the other categories, there is a mix of gasoline and diesel vehicles (see Table 2). $39 \%, 30 \%$ and $18 \%$ of the light-duty vehicles, buses, and trucks, respectively, are considered gasoline vehicles, the rest being diesel. The number of vehicles in year 2000 is taken from Borken et al. (2008), and the growth rate, as predicted in the study by Wang et al. (2006), is applied to estimate the number of vehicles for each category in 2020. Annual per-vehicle mileage estimates for each vehicle category in 2000 are obtained from Borken et al. (2008). Because 
Table 2. Number of vehicles and annual mileage.

\begin{tabular}{llll}
\hline Vehicle category & $\begin{array}{l}2000 \\
(\text { million})\end{array}$ & $\begin{array}{l}2020 \\
\text { (million) }\end{array}$ & $\begin{array}{l}\text { Annual } \\
\text { mileage } \\
(\mathrm{km})\end{array}$ \\
\hline Motorcycle & 37.718 & 81.437 & 9000 \\
Private Car (Gasoline) & 7.219 & 164.232 & 31200 \\
Light-duty vehicle (Gasoline) & 1.521 & 5.531 & 27200 \\
Light-duty vehicle (Diesel) & 2.411 & 8.767 & 23400 \\
Bus (Gasoline) & 0.397 & 1.191 & 34000 \\
Bus (Diesel) & 0.929 & 2.787 & 34000 \\
Truck (Gasoline) & 0.574 & 2.296 & 30000 \\
Truck (Diesel) & 2.659 & 10.636 & 34500 \\
Rural vehicle (Diesel) & 9.645 & 20.668 & 17500 \\
\hline
\end{tabular}

Source: The number of vehicles and annual mileage for 2000 are from Borken et al. (2008) and the growth rates for 2020 from 2000 are taken from Wang et al. (2003).

it is difficult to predict future driving patterns, we maintain the same per-vehicle annual mileage for each vehicle category in 2020. This assumption for gasoline vehicles is most likely an upper estimate, considering the estimated growth in the number of private cars between 2000 and 2020. For the diesel vehicles, however, this number may increase in 2020. Therefore, $\mathrm{CO}$ and VOC emissions may be estimated higher due to the bias in gasoline vehicles, whereas $\mathrm{NO}_{\mathrm{x}}$ and $\mathrm{PM}$ emissions may be estimated lower due to the bias in diesel vehicles. The values used for the number of vehicles and annual mileage for each vehicle category in 2000 and 2020 are summarized in Table 2.

\subsubsection{Emission factors}

Emission factors for 2000 are taken from Borken et al. (2008), and are listed in Table 3. For the sulphur content of the fuel, we use the numbers that are used in REAS PFC. It is $1200 \mathrm{ppm}$ for gasoline and $1630 \mathrm{ppm}$ for diesel (except for the Northeast China where the sulphur content is $350 \mathrm{ppm}$ ). For 2020, we develop two scenarios based on clear policy choices, rather than making assumptions about technological developments and fuel use. We develop a No-Policy (NoPol) scenario, which uses the same emission factors as in 2000; and the Euro 3 scenario, which uses emission factors taken from the Euro 3 standards for all vehicles except motorcycles and rural vehicles (these two classes of vehicles are assumed to remain at NoPol levels). Our $2020 \mathrm{NoPol}$ and Euro 3 simulations are identical except for their emission factors. Emissions allowed under Euro 3 standards are illustrated in Table 1. China nationally implemented the Euro 3 emission standards in 2008 for all categories of new vehicles except motorcycles. Here we examine the air quality implications of perfect enforcement of these standards in China in 2020.

In trying to understand Asian emissions in 2006, Zhang et al. (2009) assumed that more than $85 \%$ of gasoline vehicles would meet Euro 1 or higher emission standards by 2006, and $60 \%$ of gasoline vehicles would meet Euro 2 or Euro 3 emission standards. This rapid penetration of more stringent standards in the 5 years since the first implementation of the Euro 1 standards in 2001 is a result of the rapidly growing transport sector. Following their work, we assume that all vehicles will have control technologies that meet the Euro 3 standards by 2020 . We realize that some vehicles (especially in cities such as Beijing and Shanghai that adopted the Euro 4 standards in 2008 and 2009, respectively) will meet more stringent vehicle emission standards, while old vehicles that remain on the road will possibly not even meet the Euro 1 standards. Since these standards are currently enforced only for new vehicles, there are also uncertainties associated with emissions as vehicles age without sufficient in-use emission regulations. To simplify the matter, however, we assume that on average, Chinese vehicle emissions meet Euro 3 emission standards by 2020 in the Euro 3 scenario to quantify the air quality benefits of perfect implementation of these standards. Because there is no regulation adopted for motorcycle emissions and since it is not clear that rural vehicles would meet national regulations, we assume that the emission factors for motorcycles and rural vehicles stay the same as they are in the 2000 baseline simulation in both 2020 scenarios.

The emission factors for the Euro 3 scenario are calculated using the Computer Programme to Calculate Emissions from Road Transport (COPERT 4) model (European Environment Agency, 2009). COPERT 4 is a program that calculates emission factors of all major air pollutants $\left(\mathrm{CO}, \mathrm{NO}_{\mathrm{x}}\right.$, $\mathrm{HC}, \mathrm{PM}_{2.5}, \mathrm{NH}_{3}, \mathrm{SO}_{2}$, heavy metals) for five vehicle categories (passenger cars, light duty vehicles, heavy duty vehicles, mopeds and motorcycles) and six fuel categories (gasoline, diesel, LPG, hybrid, CNG, and biodiesel), given specific parameters for: (1) driving condition (trip length, trip time, speed); (2) meteorology (minimum and maximum temperatures, Reid Vapour Pressure); and (3) fuel information (fuel specifications such as sulphur content).

Studies have been conducted to analyze average vehicle speeds in China. For example, Cai and Xie (2007) assumed 20,40, and $80 \mathrm{~km} \mathrm{~h}^{-1}$ average speeds for urban, rural, and freeway roads, respectively. Wang et al. (2008) conducted studies comparing driving parameters for different cities. The average speed in eleven cities is calculated to be $29.1 \mathrm{~km} \mathrm{~h}^{-1}$, and thus we use $30 \mathrm{~km} \mathrm{~h}^{-1}$ for all travel in this study. The minimum and maximum monthly temperatures are calculated by taking the lowest and the highest average monthly temperatures from the 29 Chinese cities. We use $3.6^{\circ} \mathrm{C}$ and $23.8{ }^{\circ} \mathrm{C}$ as the minimum and the maximum monthly temperatures, respectively, and $64 \mathrm{kPa}$ for Reid Vapour Pressure (RVP), which measures the volatility of gasoline. Sulphur content is taken from the Euro 3 standard, which is $15 \mathrm{ppm}$ for gasoline and $35 \mathrm{ppm}$ for diesel.

The COPERT 4 program is designed for calculating vehicle emissions in Europe, and therefore does not calculate emission factors for heavy duty gasoline vehicles, as they rarely exist in Europe. They are also not common in China, making up approximately $1 \%$ of total vehicle population (see 
Table 3. List of Emission Factors $\left(\mathrm{g} \mathrm{km}^{-1}\right)$.

\begin{tabular}{lllllll}
\hline Vehicle Type & $\mathrm{CO}$ & $\mathrm{HC}$ & $\mathrm{NO}_{\mathrm{x}}$ & $\mathrm{PM}$ & $\mathrm{BC}$ & $\mathrm{OC}$ \\
\hline 2000 \& 2020 NoPol & & & & & & \\
\hline Motorcycle & 12.9 & 3.84 & 0.2 & 0.2 & 0.058 & 0.061 \\
Private Car (Gasoline) & 8.6 & 0.96 & 1.4 & 0.15 & 0.043 & 0.046 \\
Light-duty vehicle (Gasoline) & 21.8 & 1.72 & 2.7 & 0.21 & 0.061 & 0.064 \\
Light-duty vehicle (Diesel) & 1 & 0.65 & 4.3 & 0.28 & 0.159 & 0.051 \\
Bus (Gasoline) & 42.2 & 3.65 & 3.8 & 0.35 & 0.101 & 0.107 \\
Bus (Diesel) & 5.5 & 3.04 & 13.6 & 1.01 & 0.573 & 0.182 \\
Truck (Gasoline) & 44.6 & 3.86 & 4 & 0.35 & 0.101 & 0.107 \\
Truck (Diesel) & 2.6 & 1.25 & 12 & 0.62 & 0.352 & 0.112 \\
Rural vehicle (Diesel) & 1.5 & 1.7 & 1.1 & 0.2 & 0.114 & 0.036 \\
\hline 2020 Euro 3 & & & & & & \\
\hline Private Car (Gasoline) & 0.494 & 0.018 & 0.081 & 0.001 & 0.0003 & 0.0003 \\
Light-duty vehicle (Gasoline) & 3.542 & 0.04 & 0.097 & 0.001 & 0.0003 & 0.0003 \\
Light-duty vehicle (Diesel) & 0.407 & 0.091 & 1.081 & 0.058 & 0.033 & 0.0105 \\
Bus (Gasoline) & 2.1 & 0.08 & 0.13 & 0.06 & 0.017 & 0.0184 \\
Bus (Diesel) & 2.267 & 0.437 & 8.175 & 0.18 & 0.102 & 0.0325 \\
Truck (Gasoline) & 2.1 & 0.08 & 0.13 & 0.06 & 0.017 & 0.0184 \\
Truck (Diesel) & 1.413 & 0.306 & 5.304 & 0.124 & 0.07 & 0.0224 \\
Rural vehicle (Diesel) & 1.5 & 1.7 & 1.1 & 0.2 & 0.114 & 0.036 \\
\hline
\end{tabular}

Table 2), but to account for these, we used the vehicle emission standards in Japan that most closely replicate Euro 3 standards for these vehicle types. The emission factors for $\mathrm{PM}$ and $\mathrm{NO}_{\mathrm{x}}$ for heavy duty gasoline vehicles in the Euro 3 scenario are taken from the $1994 \mathrm{PM} / \mathrm{NO}_{\mathrm{x}}$ Regulation. For other species, the emission factors are taken from the 2000 New Short Term Standard. The emission factors used in this study are summarized in Table 3.

\subsection{Regional emissions}

For the three scenarios, total $\mathrm{CO}, \mathrm{NO}_{\mathrm{x}}, \mathrm{BC}, \mathrm{OC}$, and NMVOC emissions from China's road transport sector along with emissions from four other sectors (domestic, other transport, industry, and power plants) included in the REAS inventory are shown in Fig. 2. All species except OC have the lowest total emissions in the 2000 scenario and the highest emissions in the $2020 \mathrm{NoPol}$ scenario. In comparing the NoPol scenario with the 2000 baseline, China's total CO, $\mathrm{NO}_{\mathrm{x}}, \mathrm{NMVOC}$, and $\mathrm{BC}$ emissions from all anthropogenic sources increase by $62 \%, 178 \%, 162 \%$, and $43 \%$ (Table 4). The difference between the 2000 and the two 2020 scenarios is due not only to changes in the transport sector, but also in all other sectors.

OC emissions decrease in the 2020 scenarios because of the expected reduction of emissions in the residential sector. OC emissions from the transport sector increase from the 2000 baseline to the two 2020 scenarios. For CO and BC, the largest increase from the 2000 to $2020 \mathrm{NoPol}$ scenarios is due to the increase in the gasoline, and diesel vehicle emissions, respectively. For $\mathrm{NO}_{\mathrm{x}}$, we see a rapid increase in both gasoline and diesel vehicle emissions, and at the same time, the emissions from power plant sources also increase significantly. Table 4 illustrates that $\mathrm{CO}, \mathrm{NO}_{\mathrm{x}}, \mathrm{NMVOC}, \mathrm{BC}$ and OC emissions from vehicles increase by 5.9, 4.9, 3.4, 2.3 and 2.4 times in the $2020 \mathrm{NoPol}$ scenario with respect to the 2000 emissions, thereby increasing the proportion of emissions of these pollutants in China originating from vehicles.

There is seasonal variability in biomass burning and biogenic emissions, but we do not account for such seasonality in China's vehicle emissions. The previous research in Tianjin, China, Oliver (2008) has found that the summer CO emissions were $18 \%$ higher than those in spring. For $\mathrm{NO}_{\mathrm{x}}$ emissions, she found a $3 \%$ increase in the summer, and there was only a negligible difference for PM emissions. Considering the seasonal variation in $\mathrm{CO}$, it would be more realistic to include seasonality in our emissions. However, there is a lack of data and Zhang et al. (2009) also notes that there is less seasonal cycle in vehicle emissions compared to other sources in China. We thus argue that, with a lack of data, including seasonality in emissions is not possible, but we believe even without including this information we do not miss an important feature of realistic vehicle emissions due to the small magnitude of the seasonal difference.

Combining with other emissions inventories we use for non-anthropogenic sources, Fig. 3 provides the spatial distribution of the total $\mathrm{CO}, \mathrm{NO}_{\mathrm{x}}, \mathrm{BC}$ and $\mathrm{OC}$ monthly emissions for 2000 baseline, $2020 \mathrm{NoPol}$ and 2020 Euro 3 scenarios. 

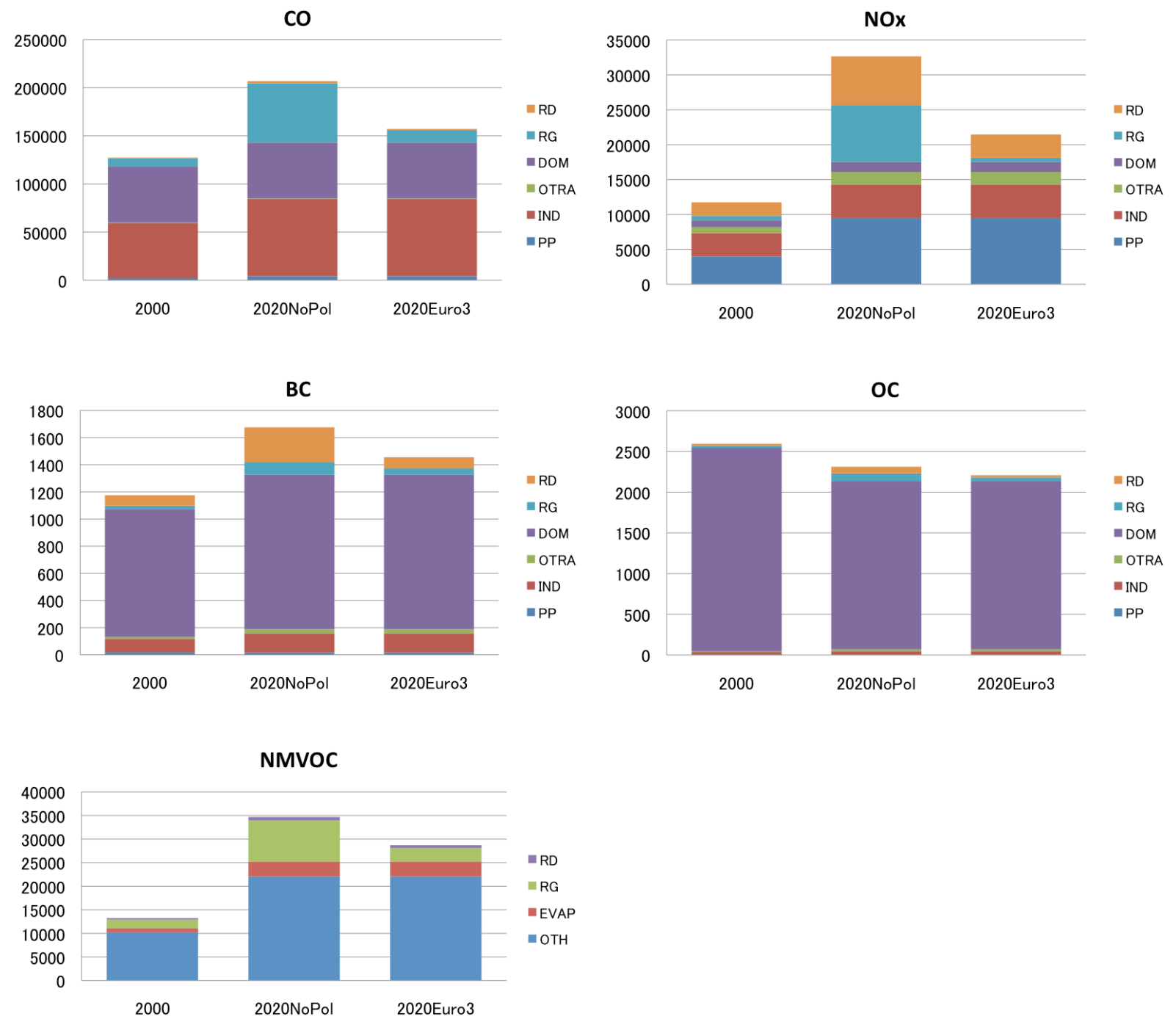

Fig. 2. Total emissions from China's six anthropogenic sectors (RD: Road Diesel, RG: Road Gasoline, DOM: domestic, OTRA: other transport sector (airplanes, ships, etc), IND: industry, and PP: power plants, EVAP: evaporative emissions, OTH: others - waste treatment, surface emissions of aircraft and ships) in the three scenarios (2000, 2020NoPol, and 2020Euro3) upper-left CO, upper-right $\mathrm{NO}_{\mathrm{x}}$, middle-left $\mathrm{BC}$, middle-right OC, lower-left NMVOC $\left(\mathrm{Gg} \mathrm{yr}^{-1}\right)$.

Here we provide the spatial distribution of emissions in April for the four species in the three scenarios. A large overall increase in these emissions in the $2020 \mathrm{NoPol}$ scenario relative to the 2000 baseline is visible in Fig. 3. The increase in emissions from the 2000 baseline to $2020 \mathrm{NoPol}$ is most visible for $\mathrm{NO}_{\mathrm{x}}$ emissions, whereas we see a decrease in the OC emissions in China except for the Beijing area. This is what we expect from the reduction in total emissions and the increase in vehicle emissions of OC, as shown in Fig. 2.

For all species, there is a significant reduction of emissions from regulation of vehicle exhaust in 2020. Table 4 shows that China's total $\mathrm{CO}, \mathrm{NO}_{\mathrm{x}}, \mathrm{NMVOCs}, \mathrm{BC}$ and $\mathrm{OC}$ emissions are reduced by $78 \%, 74 \%, 63 \%, 63 \%$ and $58 \%$, respectively, under the Euro 3 scenario relative to NoPol in 2020. Due to this reduction in the road transport sector while holding emissions from all other sources constant, the share of vehicle emissions in China's total emissions also decrease significantly in the Euro 3 scenario with respect to NoPol. For example, while the contribution of vehicles for total $\mathrm{NO}_{\mathrm{x}}$ emissions in $\mathrm{NoPol}$ is $46 \%$, it is reduced to only $18 \%$ in the Euro 3 scenario. Similarly, the share is at least halved in all pollutants by perfect implementation of the Euro 3 emission standards relative to no regulations. Emission reductions from the NoPol to Euro 3 scenario are concentrated in cities and the urban periphery, where there are vehicle emissions. Even though China's total number of vehicles increases by a factor of 4.7 in 2020 with respect to $2000, \mathrm{CO}, \mathrm{NO}_{\mathrm{x}}, \mathrm{BC}$, $\mathrm{OC}$, and NMVOC emissions from the road transport sector in the Euro 3 scenario increase by only 1.5, 1.5, 1.2, 1.4, and 1.6 , respectively. 
Table 4. Total anthropogenic emissions for each scenario in China (vehicle, total), Korea and Japan (kt year ${ }^{-1}$ ).

\begin{tabular}{lllll}
\hline Species & $\begin{array}{l}\text { China } \\
\text { (vehicle) }\end{array}$ & $\begin{array}{l}\text { China } \\
\text { (total) }\end{array}$ & Korea & Japan \\
\hline 2000 baseline & & & & \\
\hline CO & 9279 & 127461 & 4627 & 2661 \\
NO $_{\mathrm{x}}$ & 2574 & 11745 & 1559 & 1959 \\
NMVOC & 2125 & 13249 & 1134 & 1880 \\
$\mathrm{BC}$ & 105 & 1176 & 33 & 75 \\
OC & 53 & 2594 & 57 & 44 \\
\hline 2020 NoPol & & & & \\
\hline CO & 63808 & 206856 & 6736 & 1846 \\
NOx & 15130 & 32655 & 1955 & 1837 \\
NMVOC & 9442 & 34690 & 2231 & 2462 \\
BC & 350 & 1676 & 34 & 36 \\
OC & 180 & 2312 & 58 & 33 \\
\hline 2020 Euro 3 & & & & \\
\hline CO & 14111 & 157159 & 6736 & 1846 \\
NO & 3933 & 21458 & 1955 & 1837 \\
NMVOC & 3470 & 28718 & 2231 & 2462 \\
BC & 129 & 1456 & 34 & 36 \\
OC & 75 & 2208 & 58 & 33 \\
\hline
\end{tabular}

Some hotspots are also visible due to high biomass burning emissions reported in the GFED v2.1 inventory. For example, a small fire is visible in Russia, close to Mongolia and Kazakhstan border and also in Myanmar in April, as shown in Fig. 3. On these hotspots, there are high surface emissions of all species, due to forest fires. It is important to note that the same forest fire hotspots are included in 2020 as in the 2000 baseline, because the same emissions inventory is used for biomass burning in all scenarios.

\section{The atmospheric chemistry transport models}

In this study, we use the regional three-dimensional chemical transport model Weather Research and Forecasting model coupled with Chemistry (WRF/Chem) v3.1.1, with initial and lateral chemical boundary conditions taken from a simulation of the global chemical transport Model for Ozone and Related chemical Tracers (MOZART) v2.4.

\subsection{The WRF/Chem model}

We use the fully coupled "online" regional chemical transport model WRF/Chem version 3.1.1 (Grell et al., 2005, and references therein) in this study at a spatial resolution of $40 \mathrm{~km} \times 40 \mathrm{~km}$ with 31 vertical levels from the surface to $50 \mathrm{mb}$, the surface layer being approximately $12 \mathrm{~m}$ thick. The model domain is shown in Fig. 1, and covers the en-
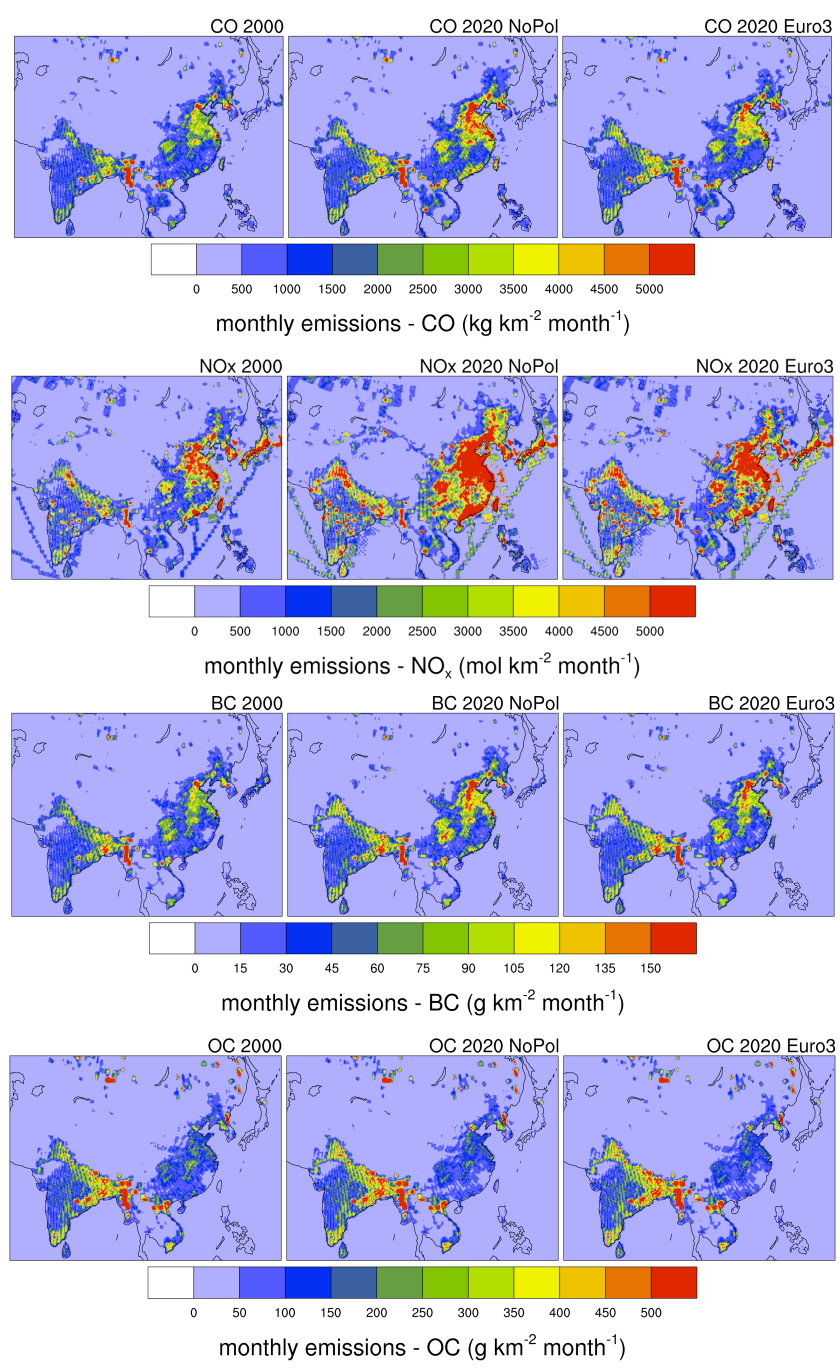

Fig. 3. The monthly mean surface emissions of $\mathrm{CO}$ $\left[\mathrm{kg} \mathrm{km}^{-2}\right.$ month $\left.^{-1}\right]$ (top), $\mathrm{NO}_{\mathrm{x}}\left[\mathrm{mol} \mathrm{km}{ }^{-1} \mathrm{month}^{-1}\right]$ (second top), BC $\left[\mathrm{g} \mathrm{km}^{-2} \mathrm{month}^{-1}\right]$ (second bottom) and OC $\left[\mathrm{g} \mathrm{km}^{-2}\right.$ month $\left.^{-1}\right]$ (bottom) in April, used in WRF/Chem for 2000 baseline, 2020 NoPol and 2020 Euro 3 scenarios.

tire East Asia region with $199 \times 149$ grid cells with a 40 $\mathrm{km}$ spacing, using a Lambert conformal map projection centered on China at $\left(32^{\circ} \mathrm{N}, 100^{\circ} \mathrm{E}\right)$. The grid-scale of $40 \mathrm{~km}$, as compared to the much coarser grids used in global chemical transport models, allows us to more precisely analyze the impact of emission changes from the road transport sector on air quality within Asia. Finer resolution is more able to resolve spatial heterogeneities in emission strengths and better simulates the non-linearities of ozone formation and loss processes (Jang et al., 1995).

In this study, the 2000 meteorological data are obtained from the National Centres for Environmental Prediction (NCEP) Global Forecast System final gridded analysis datasets. Parameters include air temperature, surface 
Table 5. List of WRF/Chem simulations.

\begin{tabular}{|c|c|c|c|c|}
\hline \multirow[t]{3}{*}{ Scenario } & \multicolumn{3}{|c|}{ Emissions in China } & \multirow{3}{*}{$\begin{array}{l}\text { Boundary } \\
\text { Condition }\end{array}$} \\
\hline & \multicolumn{2}{|c|}{ Vehicle emissions } & \multirow{2}{*}{$\begin{array}{l}\text { Other } \\
\text { emissions }\end{array}$} & \\
\hline & $\begin{array}{l}\text { Vehicle } \\
\text { number }\end{array}$ & $\begin{array}{l}\text { Emission } \\
\text { Factor }\end{array}$ & & \\
\hline 2000 & 2000 & 2000 & 2000 & 2000 \\
\hline 2020 NoPol & 2020 & 2000 & 2020PFC & 2020 SRES A2 \\
\hline 2020 Euro 3 & 2020 & 2020 Euro 3 & 2020PFC & 2020 SRES A2 \\
\hline
\end{tabular}

pressure, sea level pressure, geopotential height, temperature, sea surface temperature, soil moisture, ice extent, snow depth, relative humidity, u- and v-winds, etc. provided every six hours.

The Regional Acid Deposition version 2 (RADM2) atmospheric chemical mechanism (Stockwell et al., 1990) is used for gas-phase chemistry. This mechanism is widely used in regional atmospheric chemistry models (for examples, see Liu et al., 2008; Zhang et al., 2006). Aerosol chemistry is represented by the Model Aerosol Dynamics for Europe with the Secondary Organic Aerosol Model (MADE/SORGAM) (Ackermann et al., 1998; Schell et al., 2001). It predicts the mass of seven aerosol species (sulphate, ammonium, nitrate, sea salt, organic carbon, secondary organic aerosols, and black carbon), using three log-normal aerosol modes (Aitken, accumulation and coarse). This mechanism does not include feedbacks of aerosol concentrations on the gasphase chemistry via heterogeneous chemistry. Photolysis rates are obtained from the Fast-J photolysis scheme (Wild et al., 2000), and cumulus physics is parameterized using the Grell-3d ensemble cumulus scheme, an update of the GrellDevenyi scheme (Grell and Dévényi, 2002).

\subsection{MOZART-2}

The global three-dimensional chemical transport model, MOZART version 2.4 (Horowitz, 2006; Horowitz et al., 2003) is used in this study to provide initial and lateral boundary conditions for 23 species in WRF/Chem (e.g. CO, $\mathrm{NO}, \mathrm{NO}_{2}$, and $\mathrm{O}_{3}$ ). The horizontal resolution of MOZART-2 is $2.8^{\circ}$ latitude $\times 2.8^{\circ}$ longitude, including 34 vertical levels from the surface to $4.3 \mathrm{mb}$. Chemical and transport processes are driven by the National Center for Atmospheric Research (NCAR) MACCM3 meteorological fields for year 2000, using the same simulations as in Horowitz (2006). The SRES A2 emissions for year 2000 or 2020 are used according to the scenarios in this study.

\section{Simulations}

\subsection{Description of simulations}

In order to simulate the present and potential future impact of emissions from China's road transport sector on surface air quality in Asia, we performed the set of 3 simulations summarized in Table 5. Each scenario was run, using WRF/Chem version 3.1.1, for four months (January, April, July and October). Considering the high computational demand of WRF/Chem, four months were selected to analyze seasonal differences. For each one-month run, we used a spin-up of 2 weeks that was not included in the analysis. MOZART-2.4 was run for 2.5 years and the January, April, July and October of the last year of the simulation (year 2000 for the 2000 simulation and year 2020 for the two 2020 simulations in all cases using year 2000 meteorology) was used as the initial and lateral boundary conditions of the WRF/Chem model simulations. The same 2000 meteorology was used for all simulations, as our focus is to understand the impact that regulatory controls of vehicle emissions have on regional air quality. We do not include an analysis of the impact of these emission controls on dynamics or climate, and do not consider inter-annual variability in air quality.

\subsection{Comparison with measurements}

WRF/Chem has been evaluated over the US (Grell et al., 2005) and Mexico City (Ying et al., 2009), but only a few studies have used it to examine the East Asian region (Lin et al., 2010; Wang et al., 2010). This study is one of the first applications of the WRF/Chem model in the region, and we also use the newly modified REAS emissions inventory as well as new initial and lateral boundary conditions from MOZART-2. We therefore evaluate our simulations for the year 2000 with observations available to us from Japan, China, Korea, and Russia.

We calculate 24-h average $\mathrm{O}_{3}$ mixing ratios at each of the following 9 measurement stations in Japan for the months of January, April, July and October in 2000 for the days that have no missing values in the hourly measurements: Rishiri, Tappi, Sadoseki, Oki, Tsushima, Happo, Nikko, Hedo, and 
Table 6. Description of observational sites.

\begin{tabular}{llllll}
\hline Name & $\begin{array}{l}\text { Latitude } \\
\left({ }^{\circ} \mathrm{N}\right)\end{array}$ & $\begin{array}{l}\text { Longitude } \\
\left({ }^{\circ} \mathrm{E}\right)\end{array}$ & $\begin{array}{l}\text { Altitude } \\
(\mathrm{m})\end{array}$ & Type & Data \\
\hline Rishiri (Japan) & 45.13 & 141.24 & 40 & Remote & EANET \\
Tappi (Japan) & 41.25 & 140.35 & 106 & Remote & EANET \\
Sadoseki (Japan) & 38.25 & 138.40 & 110 & Remote & EANET \\
Oki (Japan) & 36.28 & 133.18 & 90 & Remote & EANET \\
Tsushima (Japan) & 34.23 & 129.28 & 390 & Remote & EANET \\
Happo (Japan) & 36.69 & 137.80 & 1850 & Remote & EANET \\
Nikko (Japan) & 36.78 & 139.52 & 1781 & Remote & EANET \\
Hedo (Japan) & 26.87 & 128.25 & 60 & Remote & EANET \\
Yusuhara (Japan) & 33.36 & 132.93 & 790 & Remote & EANET \\
Lin'an (China) & 30.42 & 119.73 & 132 & Rural & Wang and Mauzerall (2004) \\
Wanli (China) & 25.18 & 121.68 & - & Remote & Chou et al. (2006) \\
Cheju (Korea) & 33.30 & 126.17 & 72 & Remote & EANET \\
Imsil (Korea) & 37.70 & 127.18 & - & Rural & EANET \\
Mondy (Russia) & 51.67 & 101.51 & 2000 & Remote & EANET \\
\hline
\end{tabular}

Table 7. Statistical measures for model performance evaluation for $\mathrm{O}_{3}$ for the year 2000 .

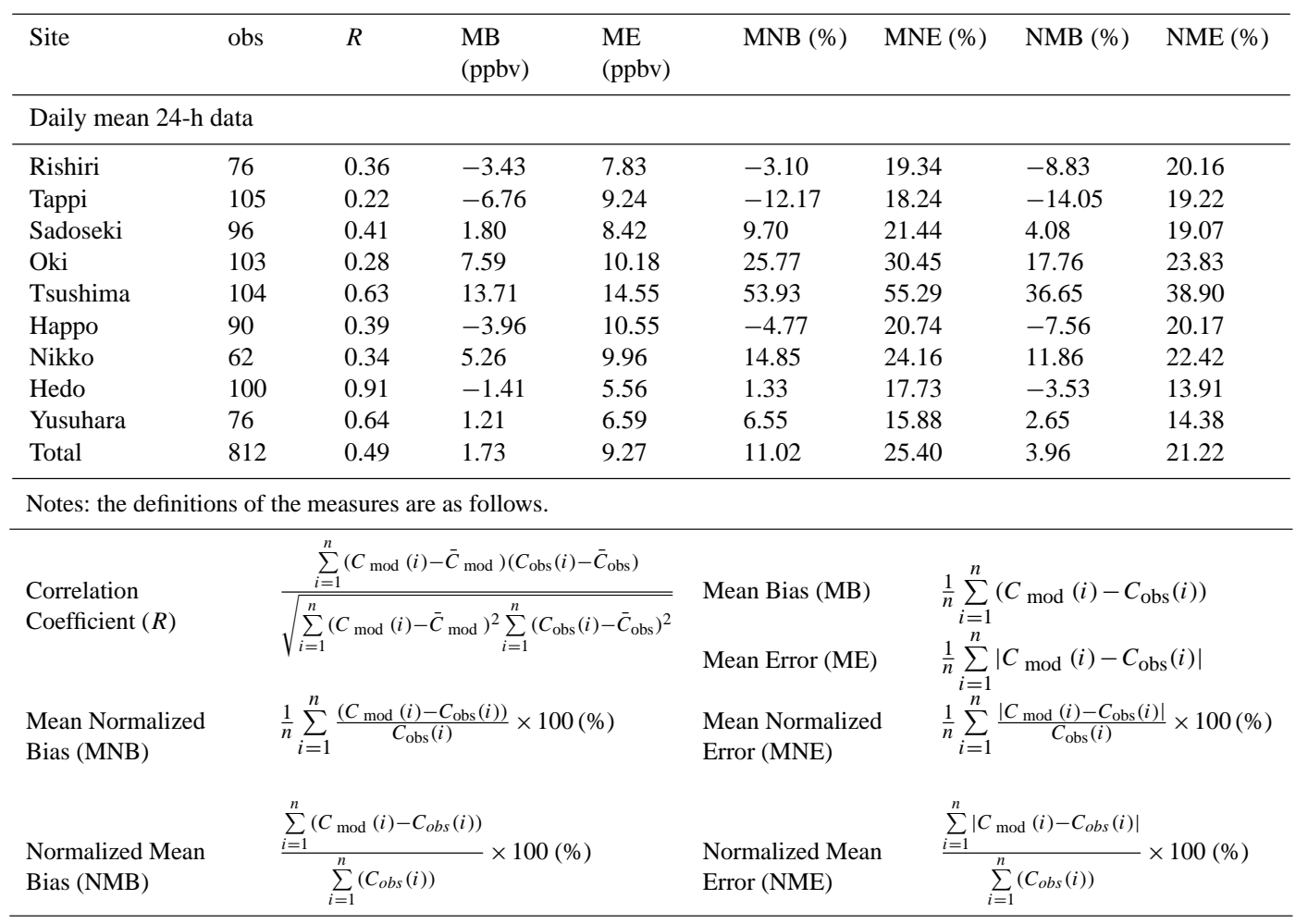

Yusuhara (see Table 6 for descriptions of these sites and Fig. 1 for their locations). These daily-averaged mixing ratios at each site are then compared with WRF/Chem results for the 2000 baseline scenario within the grid box that contains the geographical location and altitude of the stations. Observations are taken from the Acid Deposition Monitoring Network in East Asia (EANET), which is used widely for model evaluation (Carmichael et al., 2008; Han et al., 2008; Kurokawa et al., 2009; Wang et al., 2010). Seven statistical measures that are used to evaluate regional air quality models (Wang et al., 2010) are presented in Table 7 with their definitions. Model results that perfectly reproduce observations would lead to the following values: $r=1, \mathrm{MB}=0, \mathrm{ME}=0$, $\mathrm{MNB}=0, \mathrm{MNE}=0, \mathrm{NMB}=0$, and $\mathrm{NME}=0$. 

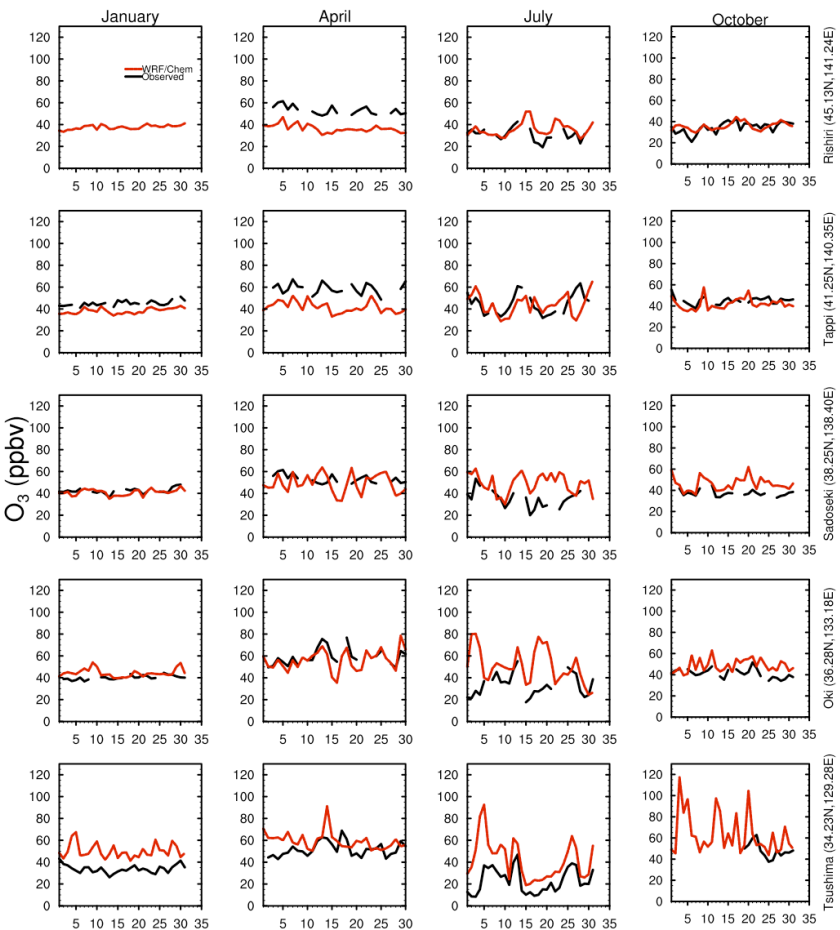

Fig. 4a. Comparison of observed (black) and simulated (red) daily mean $\mathrm{O}_{3}$ mixing ratios (ppbv) at Rishiri, Tappi, Sadoseki, Oki, and Tsushima. Observed hourly values were taken from EANET data for 2000 and averaged when there was no missing value in 24-h.
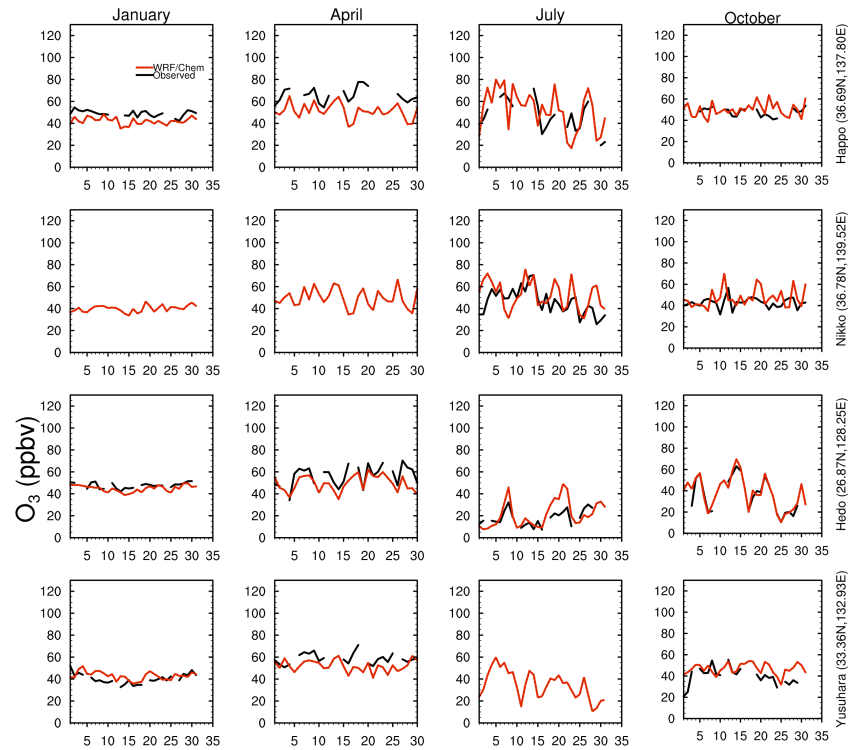

Fig. 4b. Comparison of observed (black) and simulated (red) daily mean $\mathrm{O}_{3}$ mixing ratios (ppbv) at, Happo, Nikko, Hedo, and Yusuhara. Observed hourly values were taken from EANET data for 2000 and averaged when there was no missing value in 24-h.
In addition to the statistical analyses, we also compare the monthly average of the 12-h (08:00 a.m.-08:00 p.m.) and 24$\mathrm{h}$ daily averages to the limited observational data available in similar years (1999-2002) at six other non-Japanese sites: Lin' an and Wanli in China; Cheju and Imsil in South Korea; and Mondy in Russia. The description of these 6 sites is summarized in Table 6 and their locations are also indicated in Fig. 1. We focus our evaluation on ozone (Sect. 4.2.1) and particulate matter (Sect. 4.2.2).

\subsubsection{Ozone}

We compare the daily mean $\mathrm{O}_{3}$ mixing ratios of the WRF/Chem simulations with the daily mean of the hourly observations (excluding days when there were one or more missing values at a given station) at the 9 EANET sites in Japan in Fig. 4. In Table 7 we present the statistical measures evaluating model performance at the same sites. The stations are all in remote areas that most likely represent background $\mathrm{O}_{3}$ mixing ratios. Generally, the model reproduces the measured $\mathrm{O}_{3}$ mixing ratios quite well. We find that $\mathrm{MB}$ is overall slightly positive, and the largest overestimation of the measurements takes place in Tsushima.

The correlation coefficient $(R)$ of all the observed and modelled $\mathrm{O}_{3}$ daily average mixing ratios for the four months (January, April, July and October) in 2000 is 0.49 , with values between 0.22 and 0.91, at individual sites. Combining all the model results give an MB of $1.73 \mathrm{ppbv}$ and ME of 9.27 ppbv.

We also find seasonal differences in how well model results represent observations. The largest discrepancies between the model results and observations are found in July. The MNE is over $47.5 \%$ and NME is $37 \%$ for all the 207 observations in July. These are much higher compared to the values in other months, which have values lower than $20 \%$ for both MNE and NME. The site that contributes most to this discrepancy is Tsushima, which lies on the Japanese coast facing the Korean peninsula. When the statistical values are calculated excluding Tsushima, the July MNE and NME values become $12 \%$ and $37 \%$, respectively. One of the reasons for this discrepancy with observations at this site in July is a possible overestimation of Korean emissions in the REAS inventory. From the plot of $\mathrm{O}_{3}$ fluxes (appendix), it is evident that there is a large transport of $\mathrm{O}_{3}$ from the Korean peninsula to the western coast of Japan in July. Korea's $\mathrm{CO}, \mathrm{NO}_{\mathrm{x}}, \mathrm{NMVOC}$ emissions in the REAS inventory for the year 2000 (see Table 4) are 5.1, 1.4, and 1.6 times larger than the official data, and high emissions from the Korean peninsula are visible in the total $\mathrm{CO}, \mathrm{NO}_{\mathrm{x}}, \mathrm{BC}$ and $\mathrm{OC}$ emissions shown in Fig. 3. Scaling the REAS inventory over Korea to agree with the official data may improve agreement between model results and observations.

In Fig. 5 we provide a comparison of the monthly average of 12-h (08:00 a.m.-08:00 p.m.) and 24-h mean mixing ratios of surface $\mathrm{O}_{3}$ calculated by WRF/Chem with observations in 

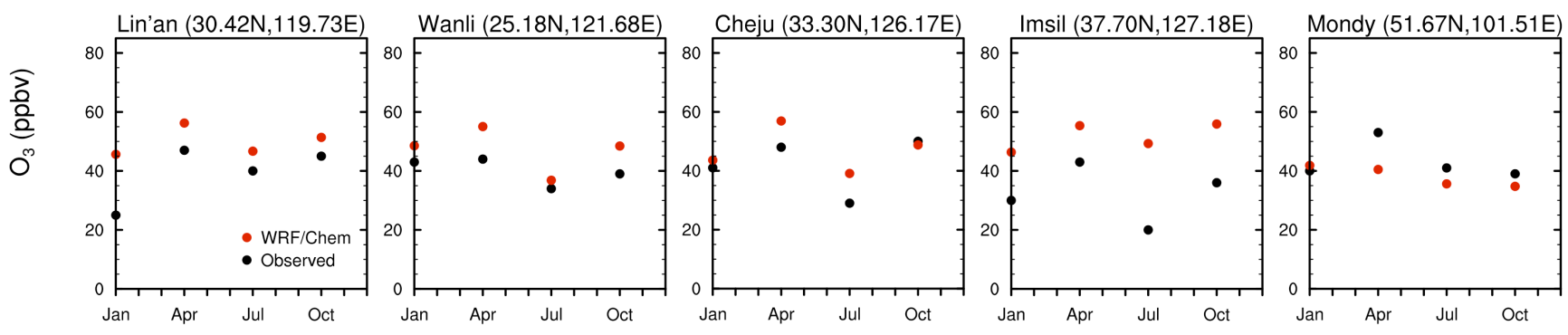

Fig. 5. Comparison of observed (black) and simulated (red) monthly mean 12-h daily average (08:00 a.m.-08:00 p.m.) $\mathrm{O}_{3}$ mixing ratios (ppbv) at Lin'an (China), comparison of observed and simulated monthly mean 24-h daily average mixing ratios (ppbv) at Wanli (China), Cheju (Korea), Imsil (Korea), and Mondy (Russia). Observed values from Lin'an were taken from Wang and Mauzerall (2004). The observations for Lin'an were made between August 1999 and July 2000. Observed values from Wanli were taken from Chou et al. (2006). Observed values from Cheju, Imsil, and Mondy are taken from EANET data for 2002.

China, South Korea and Russia in years between 1999 and 2002. Here again, model results tend to overestimate observations, but most of the model results lie within $10 \mathrm{ppbv}$ of observations. At Lin'an, China, we find only small discrepancies in the model results with observations, and the highest overestimation is found in January where model results are $20 \mathrm{ppbv}$ higher than the observed. This is similar to the seasonal biases found in other models (Kurokawa et al., 2009). On the other hand at Wanli, the model simulates observations within $10 \mathrm{ppbv}$. Lin' an is a rural site, and may be influenced by local emissions from the Yangtze River Delta region, compared to the remote site of Wanli in Taiwan (Kurokawa et al., 2009). At Imsil, $\mathrm{O}_{3}$ is overestimated by $30 \mathrm{ppbv}$ in July, but at Cheju, with less influence from local emission sources, the simulated $\mathrm{O}_{3}$ mixing ratios are within $10 \mathrm{ppbv}$ of observations in the same month. Overall, our $\mathrm{O}_{3}$ model results compare well with observations in remote areas.

\subsubsection{Particulate matter}

Figure 6 displays the 24-h average $\mathrm{PM}_{2.5}$ observations and model results for the four months in 2000 (January, April, July, and October) at Rishiri and Oki stations in Japan. Table 8 provides the statistical measures for model performance. $\mathrm{PM}_{2.5}$ measurements are limited and they are only available at these two sites in Japan. The correlation coefficient between the observed and modelled daily average for the four months (January, April, July and October) in 2000 is 0.41 with 110 observations, and the MB of these total observations is $-5.41 \mu \mathrm{g} \mathrm{m}^{-3}$. In terms of error, ME is $5.99 \mu \mathrm{g} \mathrm{m}^{-3}$, with MNE of $42.3 \%$.

Model results underestimate all observations at Rishiri with MB of $-1.48 \mu \mathrm{g} \mathrm{m}^{-3}$, but both MNB and MNE lie within an acceptable range of $-15.74 \%$ and $15.74 \%$, respectively. Model results at Oki are also significantly underestimated most of the time, while occasionally slightly overestimated. $\mathrm{MB}$ and $\mathrm{ME}$ for $\mathrm{PM}_{2.5}$ are as high as -8.14 and $9.11 \mu \mathrm{g} \mathrm{m}^{-3}$, respectively.
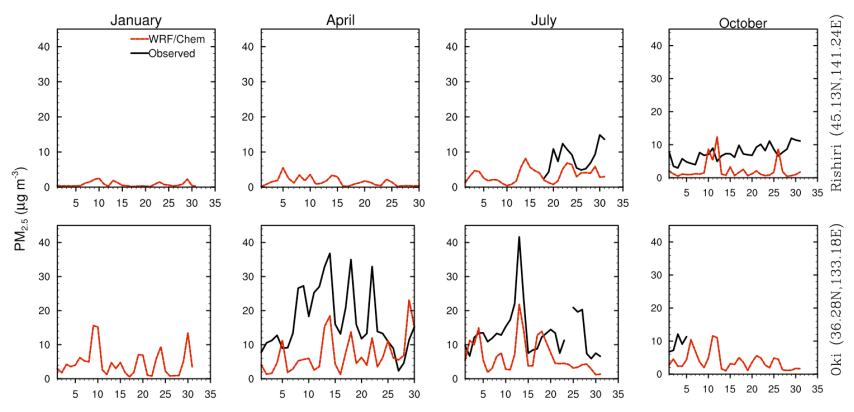

Fig. 6. Comparison of observed (black) and simulated (red) daily mean $\mathrm{PM}_{2.5}$ concentrations $\left(\mu \mathrm{g} \mathrm{m}^{-3}\right)$ at Rishiri and Oki. Observed hourly values were taken from EANET data for 2000 and averaged when there was no missing value in 24-h.

There are several reasons for the general underestimation of $\mathrm{PM}_{2.5}$. First, dust emissions are not included, and only $\mathrm{BC}$ and $\mathrm{OC}$ are prescribed as primary $\mathrm{PM}_{2.5}$ emissions in WRF/Chem. Liu et al. (2009b) calculates that $43 \%$ of total $\mathrm{PM}_{2.5}$ surface concentrations in East Asia (including Mongolia, China, Korean peninsula, and Japan) comes from dust. Zhang et al. (2009) also find that BC and OC only account for $42 \%$ of primary $\mathrm{PM}_{2.5}$ emissions in China.

Zhang et al. (2009) further note the high uncertainty of China's carbonaceous aerosol emissions, which may explain why our model results agree better with observations at Rishiri than at Oki. Rishiri is in the northern part of Hokkaido, and is more likely representative of background conditions, while Oki is closer to the Asian continent, and is more likely to be affected by transport from China. Although both places have little local pollution, the impact of prescribing less primary $\mathrm{PM}_{2.5}$ emissions is expected to have a greater influence on Oki, which is more affected by transported pollution.

Second, the underestimate may also be caused by the exclusion of aqueous phase oxidation of $\mathrm{SO}_{2}$ by $\mathrm{H}_{2} \mathrm{O}_{2}$ and $\mathrm{O}_{3}$ in the WRF/Chem model. Including only the gaseous phase 
Table 8. Statistical measures for model performance evaluation for $\mathrm{PM}_{2.5}$ for the year 2000 .

\begin{tabular}{lccllllll}
\hline Site & obs & $\mathrm{R}$ & $\begin{array}{l}\mathrm{MB} \\
\left(\mu \mathrm{g} \mathrm{m}^{-3}\right)\end{array}$ & $\begin{array}{l}\mathrm{ME} \\
\left(\mu \mathrm{g} \mathrm{m}^{-3}\right)\end{array}$ & $\begin{array}{l}\mathrm{MNB} \\
(\%)\end{array}$ & $\begin{array}{l}\mathrm{MNE} \\
(\%)\end{array}$ & $\begin{array}{l}\mathrm{NMB} \\
(\%)\end{array}$ & $\begin{array}{l}\text { NME } \\
(\%)\end{array}$ \\
\hline Daily mean 24-h data & & & & & & & & \\
\hline Rishiri & 45 & 0.43 & -1.48 & 1.48 & -15.74 & 15.74 & -19.07 & 19.07 \\
Oki & 65 & 0.45 & -8.14 & 9.11 & -46.70 & 60.69 & -54.94 & 61.47 \\
\hline Total & 110 & 0.41 & -5.41 & 5.99 & -34.03 & 42.30 & -45.39 & 50.19 \\
\hline
\end{tabular}
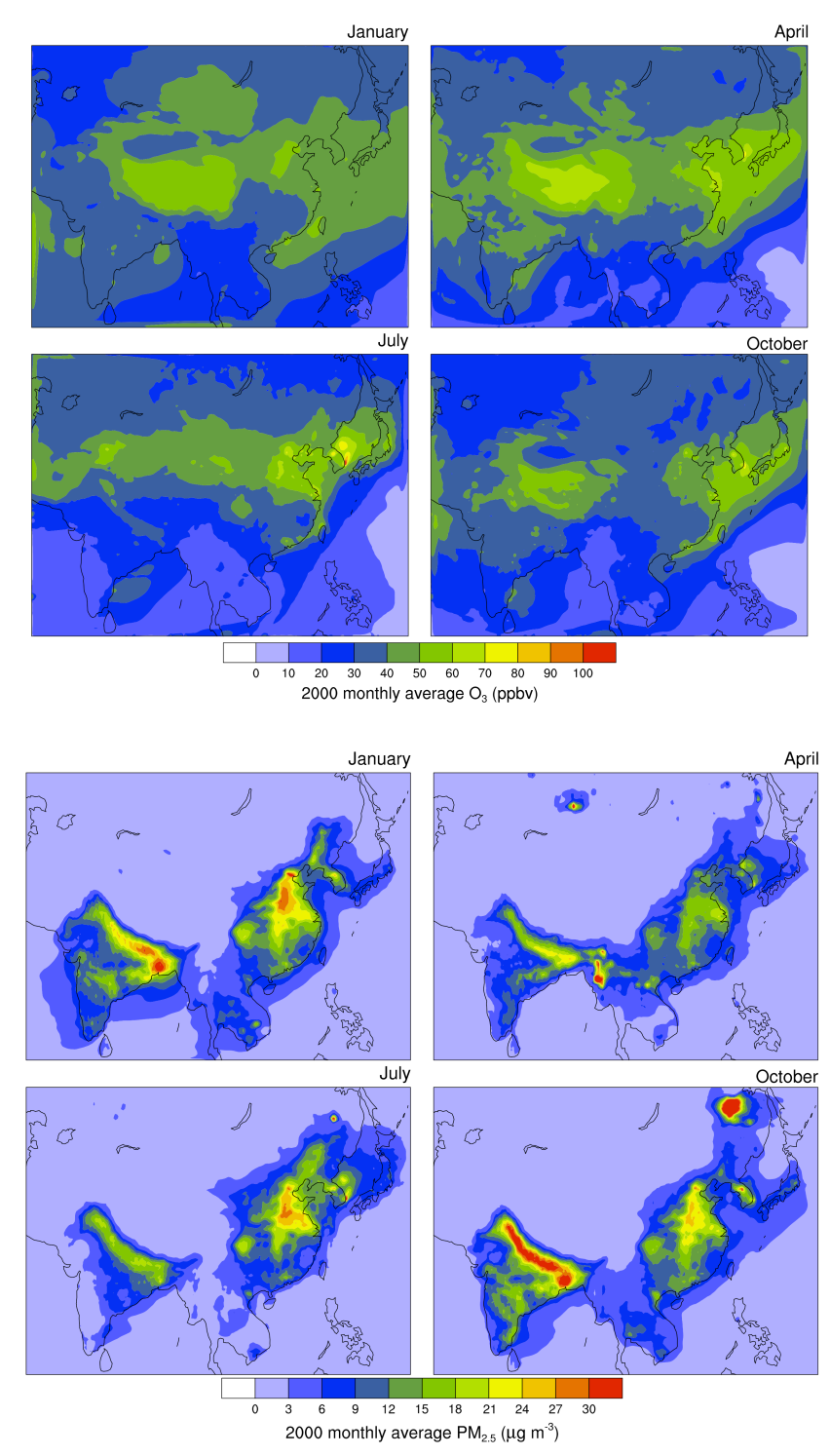

Fig. 7. The monthly mean surface $\mathrm{O}_{3}$ mixing ratios (ppbv) (top) and $\mathrm{PM}_{2.5}$ concentrations $\left(\mu \mathrm{g} \mathrm{m}^{-3}\right)$ (bottom) in January, April, July and October, modelled by WRF/Chem for the 2000 baseline. oxidation of $\mathrm{SO}_{2}$ could significantly reduce the production of sulphate, as aqueous phase oxidation could contribute approximately $80 \%$ of the sulphate production (McKeen et al., 2007; Barth et al., 2000; Koch et al., 1999).

Third, the RADM2 mechanism does not include monoterpene photochemistry, and this may also contribute to the underestimation of $\mathrm{PM}_{2.5}$. Monoterpene photochemistry is a known biogenic pathway for the formation of secondary organic aerosol (SOA). An additional reason is that RADM2 has limited oxidation pathways for anthropogenic VOCs, which may affect OC concentrations as anthropogenic VOC oxidation is important for SOA production (McKeen et al., 2007). All these factors likely contribute to underprediction of $\mathrm{PM}_{2.5}$ in our WRF/Chem model results.

\section{Scenario Simulations - surface air quality in 2000 and 2020}

\subsection{Surface air quality in $\mathbf{2 0 0 0}$}

In Fig. 7 we present monthly average surface $\mathrm{O}_{3}$ mixing ratios and $\mathrm{PM}_{2.5}$ concentrations as calculated by WRF/Chem for the year 2000 baseline scenario. The results show differences in seasonal and regional surface mixing ratios and concentrations in the four months we have analyzed.

We simulate approximately 50 ppbv $\mathrm{O}_{3}$ in urban areas with significant vehicle emissions, especially within Northeast China. In July, $\mathrm{O}_{3}$ in excess of $100 \mathrm{ppbv}$ is simulated in the area near Busan, South Korea. This is most likely an overestimate as found in Imsil in July (Sect. 4.2.1), mainly due to the overestimated emissions. Also, due to high elevation, surface $\mathrm{O}_{3}$ mixing ratios in the Tibetan plateau and the Himalayas are between 40-70 ppbv in most months.

$\mathrm{PM}_{2.5}$ has a lifetime of 1-2 weeks and, except for biomass burning, has similar emission patterns in the model throughout the year. Seasonal variability in surface concentrations results largely from changes in meteorology. We simulate low surface concentrations in April and July, and high concentrations in January and October. There is less precipitation in January and October in 2000, and this is one of the reasons for higher surface concentrations of $\mathrm{PM}_{2.5}$, due to 

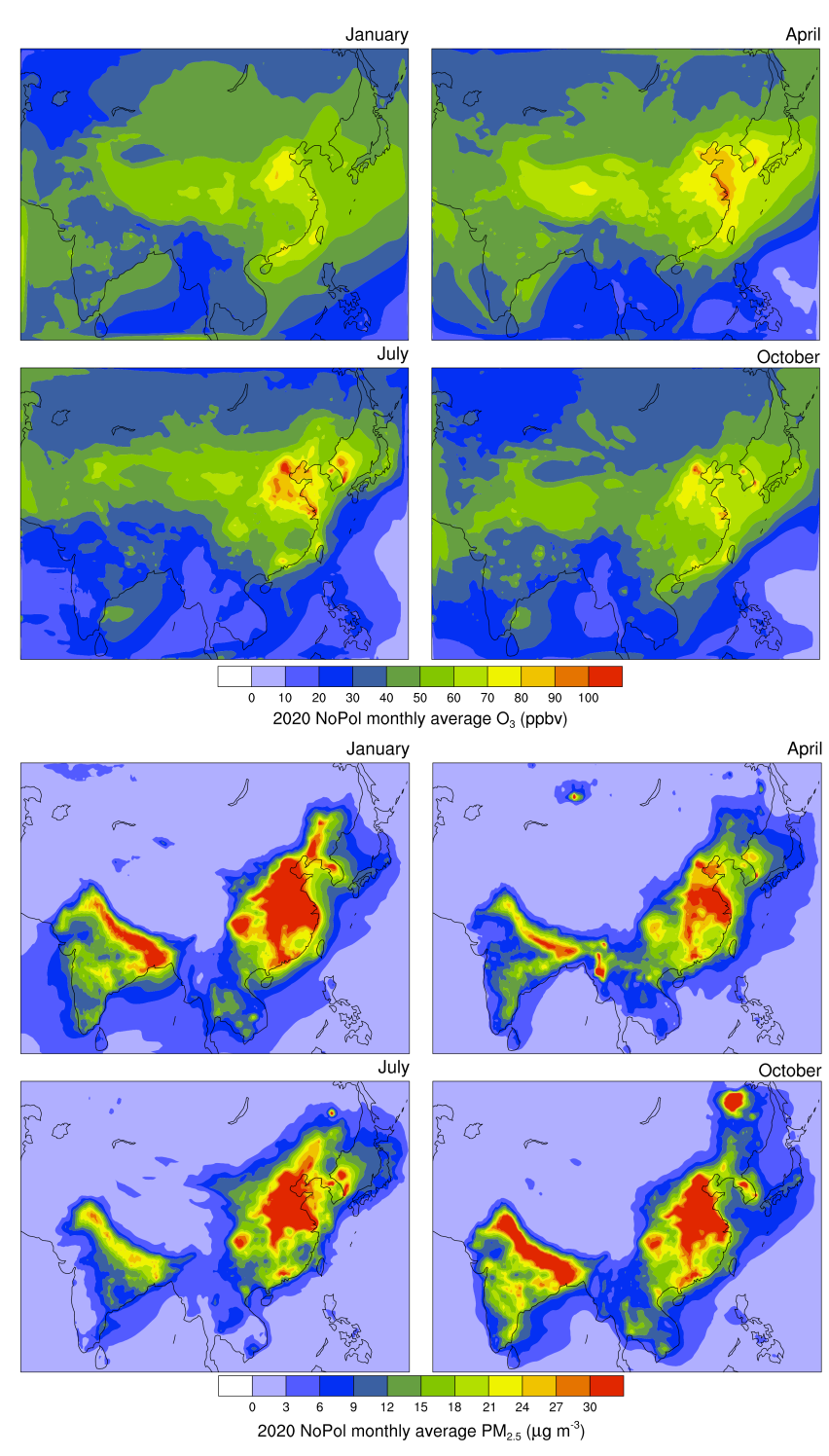

Fig. 8. The surface $\mathrm{O}_{3}$ mixing ratios [ppbv] (top), and $\mathrm{PM}_{2.5}$ concentrations $\left(\mu \mathrm{g} \mathrm{m}^{-3}\right.$ ) (bottom) in January, April, July and October modelled by WRF/Chem for 2020 NoPol scenario.

less wet scavenging. Most parts of the continent receive less than $20 \mathrm{~mm}$ of precipitation in January.

Since dust emissions are not included in our simulations, $\mathrm{PM}_{2.5}$ surface concentration is low in China in April, and we do not observe significant transfer of China's $\mathrm{PM}_{2.5}$ to the Korean peninsula or Japan in April as is often observed. These results indicate that the exclusion of dust does have large implications in the model results, as discussed in Sect. 4.2.2. Considering that the model underestimates $\mathrm{PM}_{2.5}$ surface concentrations, and we find $\mathrm{MB}$ of $-5.41 \mu \mathrm{g} \mathrm{m}^{-3}$ and MNB of $-46.7 \%$ at Oki in April, this surface concentration is a very conservative estimate and it could be significantly larger if dust or other primary $\mathrm{PM}_{2.5}$ emissions were included.

\subsection{Surface air quality differences between 2000 and 2020 NoPol}

In Fig. 8, we present monthly average surface $\mathrm{O}_{3}$ mixing ratios and $\mathrm{PM}_{2.5}$ concentrations as calculated by WRF/Chem for the $2020 \mathrm{NoPol}$ scenario. We find an excess of $100 \mathrm{ppbv}$ monthly average $\mathrm{O}_{3}$ within some parts of China in all months except January. The high mixing ratios are mainly located within Northeast China, but are also visible in and around the Korean peninsula. The monthly mean $\mathrm{PM}_{2.5}$ exceeds $30 \mu \mathrm{g} \mathrm{m}^{-3}$ in Northeast China during all 4 months. Such high-concentration hotspots are also visible in Chengdu as well as Guangzhou in Southwest and South China, respectively.

Figure 9 shows the difference in mixing ratio and concentration between the 2000 baseline and $2020 \mathrm{NoPol}$ scenarios. As illustrated in Table 4 and summarized in Sect. 2.3, emissions not only increase from China's transport sector in the 2020 NoPol scenario with respect to the baseline, but also from other sectors and countries as well. We observe higher $\mathrm{O}_{3}$ mixing ratios under $\mathrm{NoPol}$ with respect to 2000 simulations in all months in China, but the difference is especially evident in April and July. The mixing ratio increases are mainly visible in Northeast China in the greater Beijing region. Despite the reduction in China's OC emissions in the 2020 scenarios compared to $2000, \mathrm{PM}_{2.5}$ concentrations over some parts of China are still more than $30 \mu \mathrm{g} \mathrm{m}^{-3}$ higher in NoPol relative to the 2000 baseline due to the increase in BC and nitrate aerosols.

In Fig. 10, we present a cumulative frequency of $\mathrm{O}_{3}$ and $\mathrm{PM}_{2.5}$ for the three scenarios to illustrate the differences in the spread of surface mixing ratios and concentrations at the $1^{\circ}$ longitude $\times 1^{\circ}$ latitude grid level within China. In all cases, $2020 \mathrm{NoPol}$ shows the largest relative frequency for high mixing ratio/concentration levels compared to other scenarios. For $\mathrm{O}_{3}$, although the relative frequency of a monthly that is being more than $60 \mathrm{ppbv}$ is $5 \%$ in April and zero in other months in the 2000 scenario, it is $10 \%$ in January and October, $20 \%$ in July, and $30 \%$ in April in the $2020 \mathrm{NoPol}$ scenario. This reconfirms that April has the largest relative frequency of high monthly average concentrations among the four simulated months.

In contrast to $\mathrm{O}_{3}$, which shows different frequencies at all concentration levels for the three scenarios (i.e. higher frequency for the same concentration level in NoPol compared to the 2000 scenario), the cumulative frequencies within the lower range of $\mathrm{PM}_{2.5}$ concentrations are similar in all the scenarios, and they only start to diverge in the top $40 \%$.

More than $50 \%$ of the monthly average concentrations fall under the range that is less than $10 \mu \mathrm{g} \mathrm{m}^{-3} \mathrm{PM}_{2.5}$ concentrations in all scenarios. There is a larger spread in the 2020 NoPol scenario compared to the baseline, and the 90th percentile in $\mathrm{NoPol}$ is equivalent to or higher than the highest level in the same month in the 2000 scenario. January has the highest concentration levels and $5 \%$ of the grid cells within 

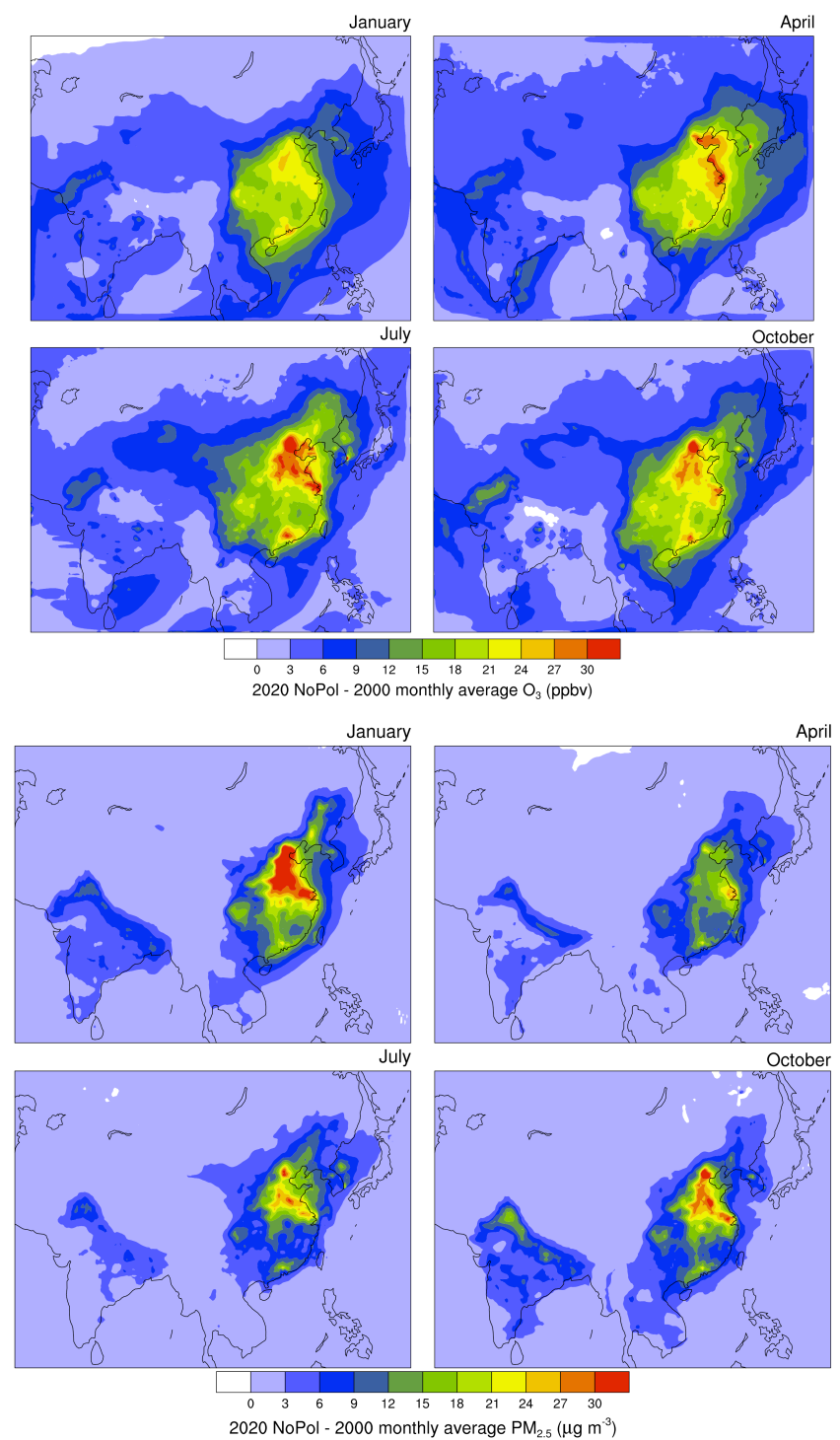

Fig. 9. Comparison of $2020 \mathrm{NoPol}$ and 2000 baseline (2020NoPol2000 baseline) surface $\mathrm{O}_{3}$ mixing ratios [ppbv] (top), and $\mathrm{PM}_{2.5}$ concentrations $\left(\mu \mathrm{g} \mathrm{m}^{-3}\right.$ ) (bottom) in January, April, July and October modelled by WRF/Chem.

China in the 2020 NoPol scenario have a January monthly average concentration higher than $50 \mu \mathrm{g} \mathrm{m}^{-3}$.

It is also important to note that populated areas are where $\mathrm{O}_{3}$ and $\mathrm{PM}_{2.5}$ concentrations are high. This has an important implication for adverse health impacts, as the decrease in these air pollutants leads to a reduction in human exposure.

\subsection{Surface air quality differences between 2020 NoPol and 2020 Euro3}

In Fig. 11, we present monthly average surface concentrations of $\mathrm{O}_{3}$ and $\mathrm{PM}_{2.5}$ as calculated by WRF/Chem for the 2020 Euro 3 scenario. In contrast to NoPol, far fewer ar- eas in China have extremely high surface $\mathrm{O}_{3}$ mixing ratios, and most places have a monthly average below $70 \mathrm{ppbv}$ in all months. As for $\mathrm{PM}_{2.5}$, although the area is considerably reduced compared to the NoPol scenario, some parts of Northeast China still shows monthly average surface concentrations above $30 \mu \mathrm{g} \mathrm{m}^{-3}$.

Figure 12 shows the difference in monthly average surface $\mathrm{O}_{3}$ mixing ratios and $\mathrm{PM}_{2.5}$ concentrations between the two 2020 scenarios. In contrast to the difference between the 2000 and $2020 \mathrm{NoPol}$ scenarios (Fig. 9), the difference between the two 2020 scenarios is due only to the reduction in vehicle emissions by implementing the Euro 3 regulations; all other emissions remain the same. Therefore, the two 2020 scenarios show similar trends, but the concentrations are much higher within urban regions of China in the NoPol scenario due to greater vehicle emissions.

As the lifetime of $\mathrm{O}_{3}$ is approximately one month and because of the non-linearities of $\mathrm{O}_{3}$ production, the implementation of Euro 3 standards in China leads to a regional reduction of surface $\mathrm{O}_{3}$. The largest difference in $\mathrm{O}_{3}$ mixing ratios between the two scenarios is found in East China, where there are projected to be a large number of vehicles. Maximum reductions in $\mathrm{O}_{3}$ mixing ratios within China from NoPol to Euro 3 are 11, 15, 21, and 22 ppbv in January, April, July, and October, respectively.

The reduction of $\mathrm{PM}_{2.5}$ in the Euro 3 scenario as compared with NoPol is also widely seen in East China. In the Northeast, a reduction of more than $10 \mu \mathrm{g} \mathrm{m}^{-3}$ is occasionally found with the highest reductions being $31,14,15$, and $26 \mu \mathrm{g} \mathrm{m}^{-3}$ for January, April, July, and October, respectively. Considering that the maximum concentration in the 2000 baseline simulation is $37 \mu \mathrm{g} \mathrm{m}^{-3}$ in January, this is a significant improvement in air quality.

Depending on the season, we also see a regional impact of China's implementation of the Euro 3 vehicle emission standards, relative to no regulations. For example, in January, the Korean peninsula, Southeast Asia, and Japan except Hokkaido experience a reduction of 2-3 ppbv or more of $\mathrm{O}_{3}$ under the Euro 3 scenario relative to NoPol. In April, the Korean peninsula sees 6-7 ppbv $\mathrm{O}_{3}$ reduction and even Hokkaido benefits from a 1-2 ppbv reduction. Similarly, a reduction of more than $10 \mu \mathrm{g} \mathrm{m}^{-3}$ is also visible in $\mathrm{PM}_{2.5}$ monthly average concentrations over the Korean peninsula in these months. In July and October, reductions are mainly found within China. Still, the Korean peninsula and Japan clearly benefit from China's implementation of the Euro 3 emission standards.

In Fig. 10, we find that there is a visible difference in the cumulative frequency of $\mathrm{O}_{3}$ and $\mathrm{PM}_{2.5}$ monthly average for the two 2020 scenarios within China. For example, whereas $36 \%$ of the grid cells within China in the NoPol scenario have more than $60 \mathrm{ppbv} \mathrm{O}_{3}$ monthly average mixing ratio in April, the relative frequency is reduced to less than $24 \%$ with the Euro 3 emission regulations. Similarly, the relative frequency of a grid cell having more than $30 \mu \mathrm{g} \mathrm{m}^{-3} \mathrm{PM}_{2.5}$ 

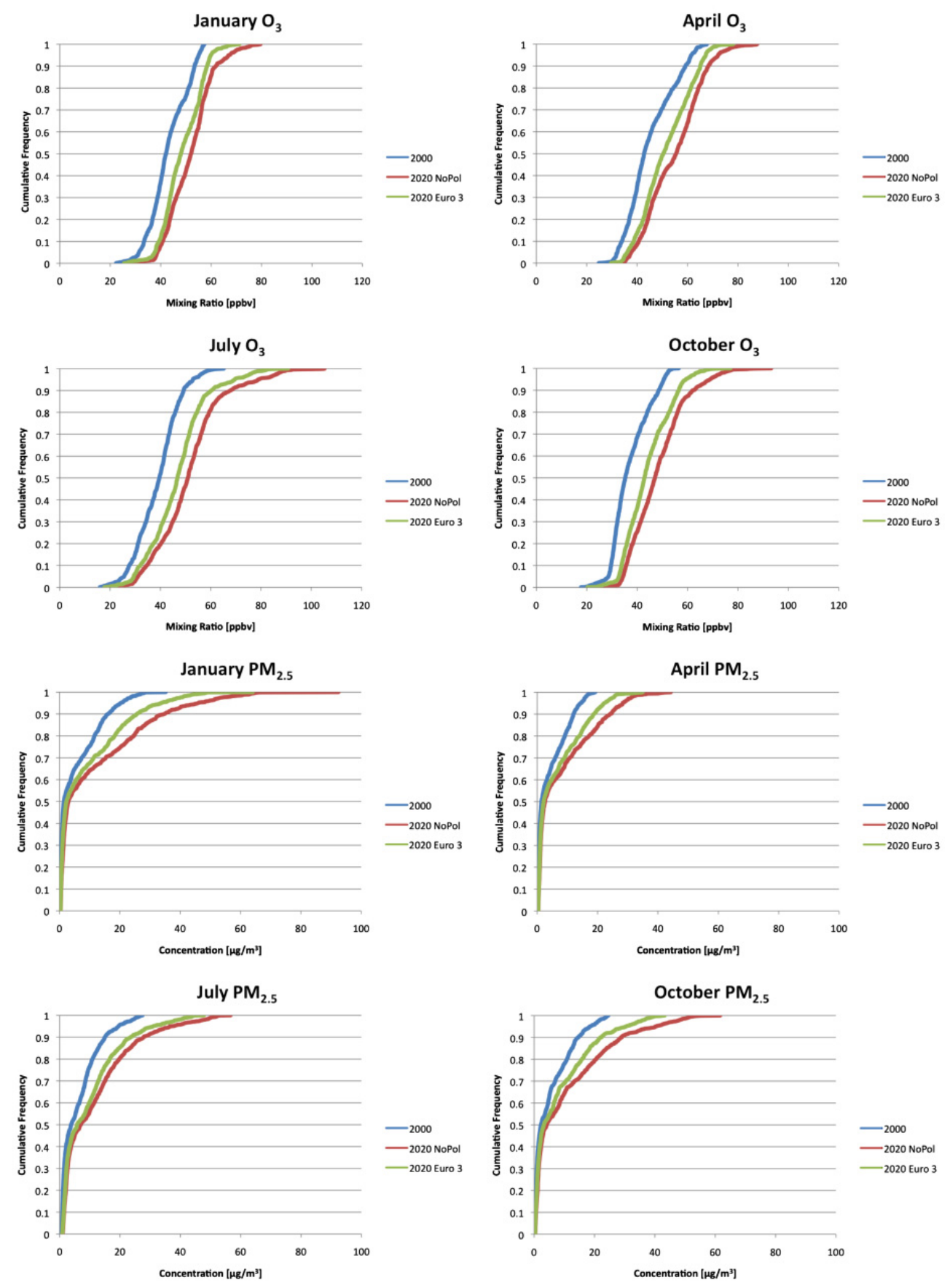

Fig. 10. Cumulative frequency of China's surface $\mathrm{O}_{3}$ mixing ratios (ppbv), and $\mathrm{PM}_{2.5}$ concentrations $\left(\mu \mathrm{g} \mathrm{m}^{-3}\right.$ ) in January, April, July and October modelled by WRF/Chem.

monthly average concentration decreases from $13 \%$ in the NoPol scenario to $6 \%$ in the Euro 3 scenario in January.

Simply by implementing the vehicle emission standards, China is more likely to be able to meet the World Health Organization's 8-h O $\mathrm{O}_{3}$ interim target-1 standards of $160 \mu \mathrm{g} \mathrm{m}^{-3}$ (approximately $81 \mathrm{ppbv}$ ) and annual mean $\mathrm{PM}_{2.5}$ interim target-1 standards of $35 \mu \mathrm{g} \mathrm{m}^{-3}$ (World Health Organization, 2006). In Table 9, we present the number of days where the 8-h average $\mathrm{O}_{3}$ and $\mathrm{PM}_{2.5}$ in Lin' an, Rishiri and Oki for each scenario is above $81 \mathrm{ppbv}$ and $35 \mu \mathrm{g} \mathrm{m}^{-3}$, respectively. The important finding is that by implementing the Euro 3 emission standards in 2020, Lin'an is able to at least keep, if not lessen, the exceedance level of $\mathrm{PM}_{2.5}$ as in 2000. Although $\mathrm{O}_{3}$ mixing ratios increase quite rapidly in 2020 due to the increased emissions in all sectors, we find that implementing the Euro 3 standards leads to a reduction of 7 exceedance 

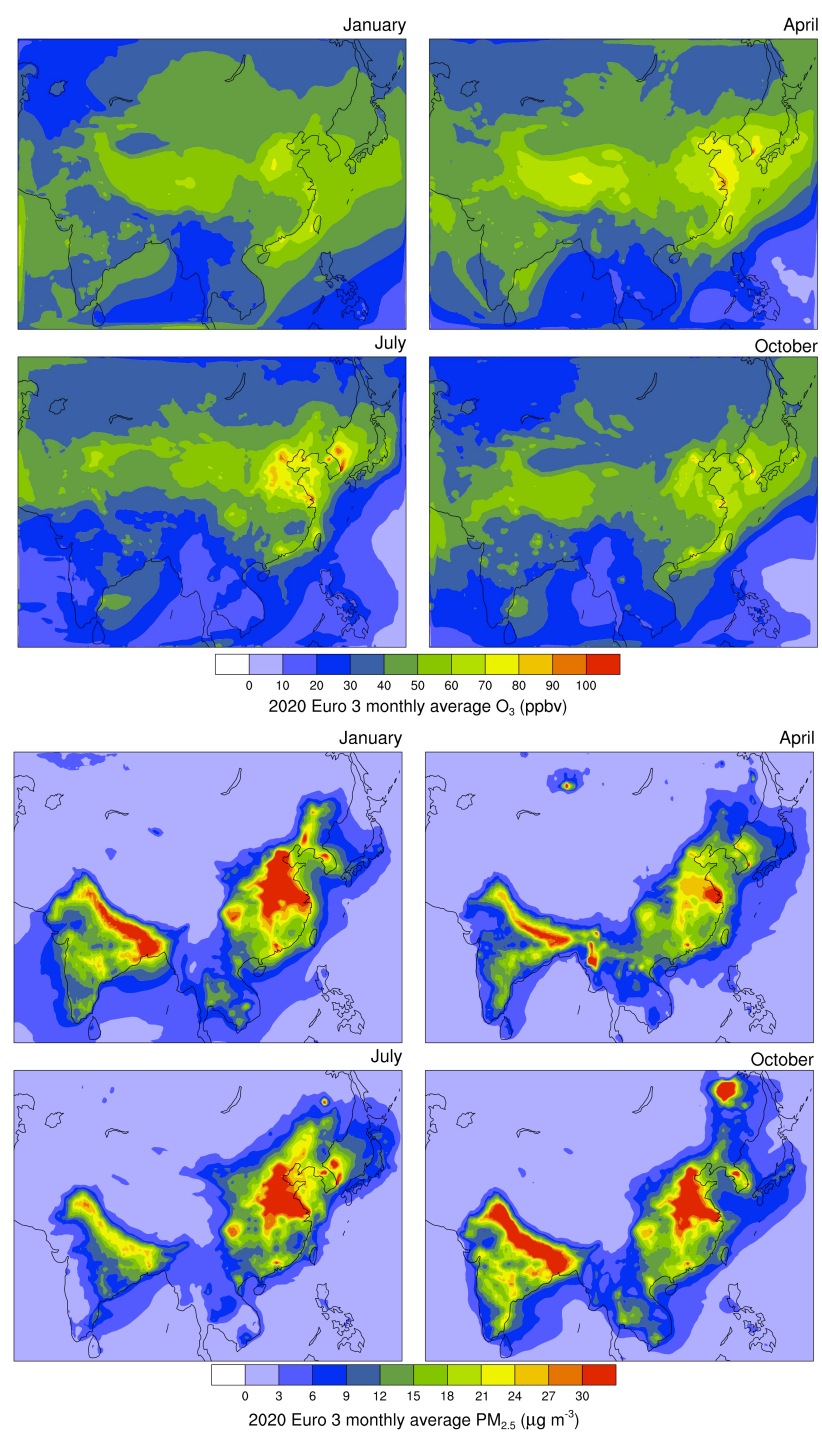

Fig. 11. The surface $\mathrm{O}_{3}$ mixing ratios [ppbv] (top) and $\mathrm{PM}_{2.5}$ concentrations $\left(\mu \mathrm{g} \mathrm{m}^{-3}\right)$ (bottom) in January April, July and October modelled by WRF/Chem for 2020 Euro 3 scenario.

days in July in Lin'an. Under Euro 3 the maximum 8-h $\mathrm{O}_{3}$ and $\mathrm{PM}_{2.5}$ average at Oki is also $1-3 \mathrm{ppbv}$ and $3-7 \mu \mathrm{g} \mathrm{m}^{-3}$ lower, respectively, than under NoPol. However, there are still many exceedance days in China even under the Euro 3 scenario (Table 9). These results illustrate that regulating vehicle emissions alone does not achieve targeted air quality in China, despite the significant improvement. Further regulations in other sectors in addition to the implementation of vehicle emission standards are essential to achieve this goal.

In summary, we find clear benefits of reducing vehicle emissions in China from this study. Full implementation of Euro 3 regulations in China result in the largest reductions in $\mathrm{O}_{3}$ and $\mathrm{PM}_{2.5}$ surface concentrations in October and January, respectively. In addition, there are large reductions in April and July for surface $\mathrm{O}_{3}$, as seen in Fig. 10. Ve-
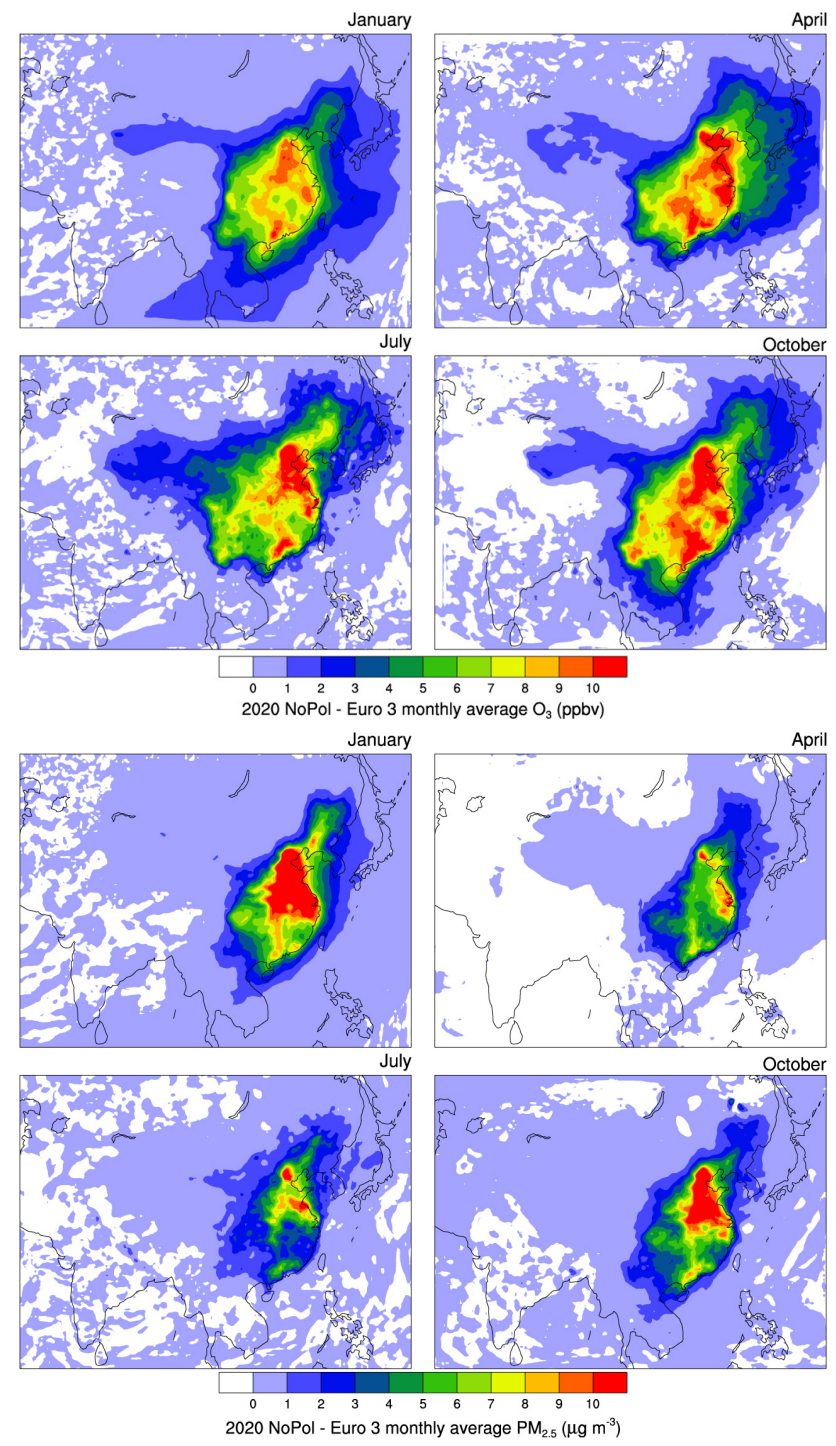

Fig. 12. Comparison of $2020 \mathrm{NoPol}$ and 2020 Euro 3 (2020 NoPol2020 Euro 3) surface $\mathrm{O}_{3}$ mixing ratios (ppbv) (top), and $\mathrm{PM}_{2.5}$ concentrations $\left(\mu \mathrm{g} \mathrm{m}^{-3}\right)$ (bottom) in January, April, July and October modelled by WRF/Chem.

hicle emission regulations lead to significant reductions in both $\mathrm{O}_{3}$ and $\mathrm{PM}_{2.5}$, because stringent vehicle emission regulations require reductions in the emissions of primary $\mathrm{PM}_{2.5}$, and in the $\mathrm{O}_{3}$ precursor species $-\mathrm{CO}, \mathrm{NO}_{\mathrm{x}}$, and NMVOCs. The three largest surface concentration reductions are seen in Beijing, Shanghai, and Guangzhou areas (see Fig. 12), where we find large vehicle emissions (Fig. 3). Although the road transport sector is responsible for a small fraction of $\mathrm{BC}$ and OC emissions (Fig. 2), with Euro 3 regulations we find significant $\mathrm{PM}_{2.5}$ surface concentration reductions, also due to less formation of nitrate aerosols from reduced $\mathrm{NO}_{\mathrm{x}}$ emissions and due to the reduced availability of excess $\mathrm{NH}_{4}$. 
Table 9a. Days exceeding the WHO interim target-1 standard for $\mathrm{O}_{3}$ (81 ppbv).

\begin{tabular}{lrrr}
\hline & 2000 & $\begin{array}{r}2020 \\
\text { NoPol }\end{array}$ & $\begin{array}{r}2020 \\
\text { Euro 3 }\end{array}$ \\
\hline Lin'an & & & \\
\hline January & 2 & 23 & 21 \\
April & 11 & 30 & 27 \\
July & 9 & 26 & 19 \\
October & 9 & 31 & 31 \\
\hline Rishiri & & & \\
\hline January & 0 & 0 & 0 \\
April & 0 & 0 & 0 \\
July & 0 & 0 & 0 \\
October & 0 & 0 & 0 \\
\hline Oki & & & \\
\hline January & 0 & 0 & 0 \\
April & 6 & 12 & 13 \\
July & 4 & 9 & 8 \\
October & 1 & 3 & 3 \\
\hline
\end{tabular}

It is important to realize that the full implementation of the Euro 6 emissions standards (proposed within Europe for adoption in 2014) relative to the Euro 3 emission standards reduce total $\mathrm{CO}$, NMVOC, $\mathrm{BC}$, and $\mathrm{OC}$ emissions (including all sectors) only by an additional $1.6 \%, 0.57 \%, 3.0 \%$, and $0.68 \% . \mathrm{NO}_{\mathrm{x}}$ emissions are the only pollutants that see a substantial further reduction of $13.5 \%$ by the full implementation of Euro 6 with respect to Euro 3. It is likely that full implementation of the Euro 6 emission standards would lead to further reductions in $\mathrm{O}_{3}$ mixing ratios relative to Euro 3. Further analysis is warranted, but unfortunately with limited computational resources available, we cannot evaluate the benefits of Euro 6 at this time.

\section{Summary and future work}

In this paper, we modify the REAS emissions inventory for China's road transport sector for 2000. We also develop two scenarios for 2020 (Euro 3 which represents implementation of existing regulation and NoPol which describes emissions as they would be without regulation), and examine the present and future impacts of China's vehicle emissions on regional air quality.

China is a major growing economy with rapidly rising number of vehicles and, as a result, increasing emissions from the road transport sector. We quantify by how much the change in emissions from one sector - road transport in China contributes to improved air quality. We find that although China's number of vehicles is expected to continue to
Table 9b. Days exceeding the WHO interim target-1 standard for $\mathrm{PM}_{2.5}\left(35 \mu \mathrm{g} \mathrm{m}^{-3}\right)$.

\begin{tabular}{lccr}
\hline & 2000 & $\begin{array}{r}2020 \\
\text { NoPol }\end{array}$ & $\begin{array}{r}2020 \\
\text { Euro 3 }\end{array}$ \\
\hline Lin'an & & & \\
\hline January & 25 & 30 & 25 \\
April & 23 & 25 & 20 \\
July & 15 & 18 & 15 \\
October & 29 & 30 & 29 \\
\hline Rishiri & & & \\
\hline January & 0 & 0 & 0 \\
April & 0 & 0 & 0 \\
July & 0 & 0 & 0 \\
October & 0 & 0 & 0 \\
\hline Oki & & & \\
\hline January & 0 & 1 & 0 \\
April & 0 & 4 & 3 \\
July & 0 & 3 & 2 \\
October & 0 & 0 & 1 \\
\hline
\end{tabular}

burgeon (e.g. 22-fold increase in private gasoline vehicles between 2000 and 2020), the perfect national implementation of the Euro 3 standards would lead to significant improvements in air quality for both China and the region, relative to no emission regulations.

We first modified the existing REAS emissions inventory to reflect newly updated Chinese vehicle emission factors for 2000, and created emission factors for 2020 in which Chinese vehicles met the Euro 3 vehicle emission standards. Applying these emission factors, we then used the regional chemical transport model WRF/Chem, with lateral and initial boundary conditions from the global model MOZART-2, to analyze the impact of China's vehicle emissions on Asian air quality. Although available surface concentration data in this region is scarce, we have used ground-based measurements in Rishiri, Tappi, Sadoseki, Oki, Tsushima, Happo, Nikko, Hedo, Yusuhara, Lin'an, Wanli, Cheju, Imsil, and Mondy to evaluate the model results for the 2000 simulation. The model results reproduce the observations quite well for $\mathrm{O}_{3}$, but underestimate $\mathrm{PM}_{2.5}$ concentrations primarily because we only include BC and OC aerosol emissions, and exclude dust in the model.

We find that a full implementation of the Euro 3 emission standards in China by 2020 would result in a significant reduction in vehicle emissions relative to no regulation (i.e., maintaining 2000 emission factors). Total Chinese vehicle emissions are reduced by $78 \%, 74 \%, 63 \%, 63 \%$ and $58 \%$ for $\mathrm{CO}, \mathrm{NO}_{\mathrm{x}}, \mathrm{NMVOCs}, \mathrm{BC}$ and $\mathrm{OC}$, respectively, by adopting the Euro 3 emission standards relative to no regulation in 2020. By using the WRF/Chem chemical transport 
model at a fine resolution of $40 \mathrm{~km} \times 40 \mathrm{~km}$, we find that there is a regional benefit, especially within Northeast Asia, from China's implementation of the Euro 3 vehicle emission standards in comparison with no regulations. Reductions in surface concentration vary by season and also by species, with reductions of surface $\mathrm{O}_{3}$ and $\mathrm{PM}_{2.5}$ of $10 \mathrm{ppbv}$ and $10 \mu \mathrm{g} \mathrm{m}^{-3}$, respectively, occurring in Eastern China. Surface $\mathrm{O}_{3}$ mixing ratio reductions of $2-6 \mathrm{ppbv}$ are also found outside of China, mainly within Northeast Asia.

As monthly average mixing ratios in the 2020 Euro 3 scenario illustrate, solely regulating vehicle emissions is not enough to bring China's air quality to a desirable level. However, this study illustrates the major importance of regulating vehicle emissions, allowing the simultaneous reductions of both surface $\mathrm{O}_{3}$ and $\mathrm{PM}_{2.5}$. For example, the World Health Organization's air quality guideline sets $100 \mathrm{\mu g} \mathrm{m}^{-3}$ (approximately $51 \mathrm{ppbv}$ ) for 8 -h mean $\mathrm{O}_{3}$ and $10 \mu \mathrm{g} \mathrm{m}^{-3}$ for annual mean $\mathrm{PM}_{2.5}$ concentrations (World Health Organization, 2006). We find that as a result of implementing the Euro 3 regulations, the relative frequency of the $\mathrm{O}_{3}$ mixing ratios in excess of $51 \mathrm{ppbv}$ is reduced on average by $13.5 \%$. Similarly, the relative frequency of $\mathrm{PM}_{2.5}$ concentrations in excess of $10 \mu \mathrm{g} \mathrm{m}^{-3}$ is reduced on average by $4.5 \%$. Large reductions in both species were possible as vehicle emissions include most of the $\mathrm{O}_{3}$ precursor species as well as primary $\mathrm{PM}_{2.5}$. However, to bring surface $\mathrm{O}_{3}$ mixing ratios and $\mathrm{PM}_{2.5}$ concentrations down further in China, it is also essential to reduce emissions from power plants and industry for the former, and from the domestic sector for the latter.

There are uncertainties associated with this study, and we have highlighted the importance of emission inventories in this paper. We expect that better data on Korean emissions and more information on China's driving patterns as well as the regional differences in vehicle types and age would significantly improve this analysis. Furthermore, as vehicle emissions vary at the regional level, more observational data at a finer scale within China is essential to evaluate and improve atmospheric chemistry models of East Asia.

Our main objective was to explore the consequences of vehicle emission regulations in China on regional air quality, but there are other important additional impacts. Considering the adverse impacts of $\mathrm{O}_{3}$ and $\mathrm{PM}_{2.5}$ on human health and agriculture, China's full implementation of stringent vehicle emission standards could lead to a significant reduction in premature mortality and result in increased agricultural yields (Shindell et al., 2011). Furthermore, because $\mathrm{O}_{3}$ and $\mathrm{BC}$ also have a positive radiative forcing, China's vehicle regulations may also lead to a reduction in climate warming. Analysis of these issues is beyond the scope of this paper, but is worthy of further investigation in the future.

Acknowledgements. We thank the Geophysical Fluid Dynamics Laboratory for computational resources. The NCEP GFS data used for this study are from the Research Data Archive (RDA) which is maintained by the Computational and Information
Systems Laboratory (CISL) at the National Center for Atmospheric Research (NCAR). NCAR is sponsored by the National Science Foundation (NSF). The original data are available from the RDA (http://dss.ucar.edu) in datasetnumber ds083.2

Edited by: B. N. Duncan

\section{References}

Ackermann, I. J., Hass, H., Memmesheimer, M., Ebel, A., Binkowski, F. S., and Shankar, U.: Modal aerosol dynamics model for Europe: Development and first applications, Atmos. Environ., 32(17), 2981-2999, 1998.

Akimoto, H.: Global air quality and pollution, Science, 302, 17161719, 2003.

Andreae, M. O., Jones, C. D., and Cox, P. M.: Strong present-day aerosol cooling implies a hot future, Nature, 435(7046), 11871190, 2005.

Anenberg, S. C., West, J. J., Fiore, A. M., Jaffe, D. A., Prather, M. J., Bergmann, D., Cuvelier, K., Dentener, F. J., Duncan, B. N., Gauss, M., Hess, P., Jonson, J. E., Lupu, A., MacKenzie, I. A., Marmer, E., Park, R. J., Sanderson, M. G., Schultz, M., Shindell, D. T., Szopa, S., Vivanco, M. G., Wild, O., and Zeng, G.: Intercontinental Impacts of Ozone Pollution on Human Mortality, Environ. Sci. Technol., 43 (17), 6482-6487, 2009.

Avnery, S., Mauzerall, D. L., Liu, J., Horowitz, L. W.: Global crop yield reductions due to surface ozone exposure: 1. Year 2000 crop production losses and economic damage. Atmos. Environ., 45(13), 2284-2296, 2011.

Barth, M. C., Rasch, P. J., Kiehl, J. T., Benkovitz, C. M., and Schwartz, S. E.: Sulfur chemistry in the National Center for Atmospheric Research Community Climate Model: Description evaluation features and sensitivity to aqueous chemistry, J. Geophys. Res., 105(D1), 1387-1415, 2000.

Borken, J., Bei, X., Jiang, Y., and Merétei, T.: Road transportation in China: How big are fuel consumption and pollutant emissions really?, 87th Annual Meeting Transportation Research Board Abstract, Washington, DC, 2008.

Cai, H. and Xie, S.: Estimation of vehicular emission inventories in China from 1980 to 2005, Atmos. Environ., 41(39), 8963-8979, 2007.

Carmichael, G. R., Sakurai, T., Streets, D., Hozumi, Y., Ueda, H., Park, S. U., Fung, C., Han, Z., Kajino, M., Engardt, M., Bennet, C., Hayami, H., Sartelet, K., Holloway, T., Wang, Z., Kannari, A., Fu, J., Matsuda, K., Thongboonchoo, N., and Amann, M.: MICS-Asia II: the model intercomparison study for Asia Phase II methodology and overview of findings, Atmos. Environ., 42(15), 3468-3490, 2008.

Chou, C. C.-K., Liu, S. C., Lin C.-Y., Shiu, C.-J., and Chang, K.-H. : The trend of surface ozone in Taipei, Taiwan, and its causes: Implications for ozone control strategies, Atmos. Environ., 40(21), 3898-3908, 2006.

Dingenen, R. V., Dentener, F. J., Raes, F., Krol, M. C., Emberson, L., and Cofala, J.: The global impact of ozone on agricultural crop yields under current and future air quality legislation, Atmos. Environ., 43(3), 604-618, 2009.

Dockery, D. W., Pope, C. A., Xu, X., Spengler, J. D., Ware, J. H., Fay, M. E., Ferris, B. G., and Speizer, F. E.: An Association 
between Air Pollution and Mortality in Six US Cities, N. Engl. J. Med., 329(24), 1753-1759, 1993.

European Environment Agency: EMEP/CORINAIR Atmospheric Emissions Inventory Guidebook - 2009, Copenhagen, 2009.

Fiore, A. M., Dentener, F. J, Wild, O., Cuvelier, C., Schultz, M. G., Hess, P., Textor, C., Schulz, M., Doherty, R. M., Horowitz, L. W., MacKenzie, I. A., Sanderson, M. G., Shindell, D. T., Stevenson, D. S., Szopa, S., Van Dingenen, R., Zeng, G., Atherton, C., Bergmann, D., Bey, I., Carmichael, G., Collins, W. J., Duncan, B. N., Faluvegi, G., Folberth, G., Gauss, M., Gong, S., Hauglustaine, D., Holloway, T., Isaksen, I. S. A., Jacob, D. J., Jonson, J. E., Kaminski, J. W., Keating, T. J., Lupu, A., Marmer, E., Montanaro, V., Park, R. J., Pitari, G., Pringle, K. J., Pyle, J. A., Schroeder, S., Vivanco, M. G., Wind, P., Wojcik, G., Wu, S., and Zuber, A.: Multimodel estimates of intercontinental sourcereceptor relationships for ozone pollution, J. Geophys. Res., 114, D04301, doi:10.1029/2008JD010816, 2009.

Forster, P., Ramaswamy, V., Artaxo, P., Berntsen, T. Betts, R., Fahey, D. W., Haywood, J., Lean, J., Lowe, D. C., Myhre, G., Nganga, J., Prinn, R., Raga, G., Schulz, M. and Van Dorland, R.: Changes in atmospheric constituents and in radiative forcing, in: Climate Change 2007: The Physical Science Basis. Contribution of Working Group I to the 4th, Assessment Report of the intergovernmental Panel on Climate Change, Cambridge University Press, 2007.

Granier, C., Lamarque, J. F., Mieville, A., Muller, J. F., Olivier, J., Orlando, J., Peters, J., Petron, G., Tyndall, G., and Wallens, S.: POET, a database of surface emissions of ozone precursors, available at: http://www.aero.jussieu.fr/projet/ACCENT/POET. php, 2005.

Grell, G. A. and Dévényi, G.: A generalized approach to parameterizing convection combining ensemble and data assimilation techniques, Geophys. Res. Lett., 29(14), 1693, doi:10.1029/2002GL015311, 2002.

Grell, G. A., Peckham, S. E., Schmitz, R., McKeen, S. A., Frost, G., Skamarock, W. C., and Eder, B.: Fully coupled "online" chemistry with the WRF model, Atmos. Environ., 39(37), 6957-6975, 2005.

Han, Z., Sakurai, T., Ueda, H., Carmichael, G. R., Streets, D., Hayami, H., Wang, Z., Holloway, T., Engardt, M., Hozumi, Y., Park, S. U., Kajino, M., Sartelet, K., Fung, C., Bennet, C., Thongboonchoo, N., Tang, Y., Chang, A., Matsuda, K., and Amann, M.: MICS-Asia II: model intercomparison and evaluation of ozone and relevant species, Atmos. Environ., 42(14), 3491-3509, 2008.

Hao, J., Hu, J., and Lixin, F.: Controlling vehicular emissions in Beijing during the last decade, Transportation Research Part A, 40, 639-651, 2006.

Horowitz, L. W.: Past, present, and future concentrations of tropospheric ozone and aerosols: Methodology, ozone evaluation, and sensitivity to aerosol wet removal, J. Geophys. Res., 111, D22211, doi:10.1029/2005JD006937, 2006.

Horowitz, L. W., Walters, S., Mauzerall, D. L., Emmons, L. K., Rasch, P. J., Granier, C., Tie, X., Lamarque, J.-F., Schultz, M. G., Tyndall, G. S., Orlando, J. J., andn Brasseur, G. P.: A global simulation of tropospheric ozone and related tracers: Description and evaluation of MOZART, version 2, J. Geophys. Res., 108(D24), 4784, doi:10.1029/2002JD002853, 2003.

Intergovernmental Panel on Climate Change (IPCC): Special Re- port on Emissions Scenarios: A Special Report of Working Group III of the Intergovernmental Panel on Climate Change, Cambridge University Press, Cambridge, UK, 2000.

Jang, J-C. C., Jeffries, H. E., Byun, D., and Pleim, J. E.: Sensitivity of ozone to model grid resolution - I. Application of high-resolution regional acid deposition model, Atmos. Environ., 29(21), 3085-3100, 1995.

Klimont, Z., Cofala, J., Xing, J., Wei, W., Zhang, C., Wang, S., Kejun, J., Bhandari, P., Mathur, R., Purohit, P., Rafaj, P., Chambers, A., and Amann, M.: Projections of $\mathrm{SO}_{2}, \mathrm{NO}_{\mathrm{x}}$ and carbonaceous aerosols emissions in Asia, Tellus B, 61, 602-617, 2009.

Koch, D., Jacob, D., Tegen, I., Rind, D., and Chin, M.: Tropospheric sulphur simulation and sulphate direct radiative forcing in the Goddard Institute for Space Studies general circulation model, J. Geophys. Res., 104(D19), 23799-23822, 1999.

Kurokawa, J., Ohara, T., Uno, I., Hayasaki, M., and Tanimoto, H.: Influence of meteorological variability on interannual variations of springtime boundary layer ozone over Japan during 19812005, Atmos. Chem. Phys., 9, 6287-6304, doi:10.5194/acp-96287-2009, 2009.

Levy, J. I., Carrothers, T. J., Tuomisto, J. T., Hammitt, J. K., and Evans, J. S.: Assessing the public health benefits of reduced ozone concentrations, Environ. Health Persp., 109(12), 12151226, 2001.

Lin, M., Holloway, T., Carmichael, G. R., and Fiore, A. M.: Quantifying pollution inflow and outflow over East Asia in spring with regional and global models, Atmos. Chem. Phys., 10, 42214239, doi:10.5194/acp-10-4221-2010, 2010.

Liu, C.-M., Yeh, M.-T., Paul, S., Lee, Y.-C., Jacob, D. J., Fu, M., Woo, J.-H., Carmichael, G. R., and Streets, D. G.: Effect of anthropogenic emissions in East Asia on regional ozone levels during spring cold continental outbreaks near Taiwan: A case study, Environ. Modelling. Software., 23(5), 579-591, 2008.

Liu, J., Mauzerall, D. L., and Horowitz, L. W.: Evaluating intercontinental transport of fine aerosols: (2) Global Health Impacts, Atmos. Environ., 43(28), 4339-4347, 2009a.

Liu, J., Mauzerall, D. L., Horowitz, L. W., Ginoux, P., and Fiore, A. M.: Evaluating inter-continental transport of fine aerosols: (1) Methodology, global aerosol distribution and optical depth, Atmos. Environ., 43(28), 4327-4338, 2009b.

McKeen, S., Chung, S. H., Wilczak, J., Grell, G., Djalalova, I., Peckham, S., Gong, W., Bouchet, V., Moffet, R., Tang, Y., Carmichael, G. R., Mathur, R., and Yu, S.: Evaluation of several $\mathrm{PM}_{2.5}$ forecast models using data collected during the ICARTT/NEAQS 2004 field study, J. Geophys. Res., 112, D10S20, doi:10.1029/2006JD007608, 2007.

Ohara, T., Akimoto, H., Kurokawa, J., Horii, N., Yamaji, K., Yan, X., and Hayasaka, T.: An Asian emission inventory of anthropogenic emission sources for the period 19802020, Atmos. Chem. Phys., 7, 4419-4444, doi:10.5194/acp-7-4419-2007, 2007.

Oliver, H. H.: In-Use Vehicle Emissions in China Tianjin Study. Discussion Paper, 2008, available at: http://belfercenter.ksg.harvard.edu/files/2008_Oliver_In-use Vehicle_Emissions_Tianjin.pdf, 2008.

Richter, A., Burrows, J., Nüß, H., Granier, C., and Niemeier, U.: Increase in tropospheric nitrogen dioxide over China observed from space, Nature, 437, 129-132, doi:10.1038/nature04092, 2005. 
Schell, B., Ackermann, I. J., Hass, H., Binkowski, F. S., and Ebel, A.: Modeling the formation of secondary organic aerosol within a comprehensive air quality model system, J. Geophys. Res., 106, 28275-28293, 2001.

Schwartz, J., Coull, B. Laden, F. and Ryan, L.: The effect of dose and timing of dose on the association between airborne particles and survival, Environ. Health. Persp., 116(1), 64-69, 2008.

Shindell, D., Lamarque, J.-F., Unger, N., Koch, D., Faluvegi, G., Bauer, S., Ammann, M., Cofala, J., and Teich, H.: Climate forcing and air quality change due to regional emissions reductions by economic sector, Atmos. Chem. Phys., 8, 7101-7113, doi:10.5194/acp-8-7101-2008, 2008.

Shindell, D., Faluvegi, G., Koch, D. M., Schmidt, A. G., Unger, N., and Bauer, S.: Improved attribution of climate forcing to emissions, Science, 326, 716-718, 2009.

Shindell, D., Faluvegi, G., Walsh, M., Anenberg, S. C., Dingenen, R. V., Muller, N. Z., Austin, J., Koch, D., and Milly, G.: Climate, health, agricultural and economic impacts of tighter vehicleemission standards, Nature Climate Change, 1, 59-66, 2011.

Stockwell, W. R., Middleton, P., and Chang, J.: The second generation regional acid deposition model chemical mechanism for regional air quality modelling, J. Geophys. Res., 95(D10), 1634316367, 1990.

Tsigaridis, K., Krol, M., Dentener, F. J., Balkanski, Y., Lathiére, J., Metzger, S., Hauglustaine, D. A., and Kanakidou, M.: Change in global aerosol composition since preindustrial times, Atmos. Chem. Phys., 6, 5143-5162, doi:10.5194/acp-6-5143-2006, 2006.

Unger, N., Shindell, D. T., Koch, D. M., Amann, M., Cofala, J., and Streets, D. G.: Influences of man-made emissions and climate changes on tropospheric ozone, methane, and sulphate at 2030 from a broad range of possible futures. J. Geophys. Res., 111, D12313, doi:10.1029/2005JD006518, 2006.

van der A, R. J., Peters, D. H. M. U., Eskes, H., Boersma, K. F., Van Roozendael, M., De Smedt, I., and Kelder, H. M.: Detection of the trend and seasonal variation in tropospheric $\mathrm{NO}_{2}$ over China, J. Geophys. Res., 111, D12317, doi:10.1029/2005JD006594, 2006.

van der Werf, G. R., Randerson, J. T., Giglio, L., Collatz, G. J., Kasibhatla, P. S., and Arellano Jr., A. F.: Interannual variability in global biomass burning emissions from 1997 to 2004, Atmos. Chem. Phys., 6, 3423-3441, doi:10.5194/acp-6-3423-2006, 2006.

Vingarzan, R.: A review of surface ozone background levels and trends. Atmos. Environ., 38(21), 3431-3442, 2004.
Volz, A. and Kley, D.: Evaluation of the Montsouris series of measurements made in the nineteenth century, Nature, 332, 240-242, 1988.

Wang, X. and Mauzerall, D. L.: Characterizing distributions of surface ozone and its impact on grain production in China, Japan and South Korea: 1990 and 2020, Atmos. Environ., 38(26), 4383-4402, 2004.

Wang, M., Huo, H., Johnson, L., and He, D.: Projection of Chinese motor vehicle growth, oil Demand, and $\mathrm{CO}_{2}$ emissions through 2050, Argonne National Laboratory, 2006.

Wang, Q., Huo, H., He, K., Yao, Z., and Zhang, Q.: Characterization of vehicle driving patterns and development of driving cycles in Chinese cities, Trans. Res. Part D, 13(5), 289-297, 2008.

Wang, X., Liang, X.-Z., Jiang, W., Tao, Z., Wang, J. X.-L., Liu, H., Han, Z., Liu, S., Zhang, Y., Grell, G. A., and Peckham, S. E.: WRF-Chem simulation of East Asian air quality: Sensitivity to temporal and vertical emissions distributions, Atmos. Environ., 44(5), 660-669, 2010.

West, J. J., Naik, V., Horowitz, L. W., and Fiore, A. M.: Effect of regional precursor emission controls on long-range ozone transport - Part 2: Steady-state changes in ozone air quality and impacts on human mortality, Atmos. Chem. Phys., 9, 6095-6107, doi:10.5194/acp-9-6095-2009, 2009.

Westerdahl, D., Wang, X., Pan, X., Zhang, K. M.: Characterization of on-road vehicle emission factors and microenvironmental air quality in Beijing, China, Atmos. Environ., 43(3), 697-705, 2009.

Wild, O., Zhu, X., and Prather, M. J.: FAST-J: accurate simulation of in- and below-cloud photolysis in tropospheric chemical models, J. Atmos. Chem., 37, 245-282, 2000.

World Health Organization: WHO Air quality guidelines for particulate matter, ozone, nitrogen dioxide and sulfur dioxide, 2006.

Ying, Z., Tie, X., and Li, G.: Sensitivity of ozone concentrations to diurnal variations of surface emissions in Mexico city: a WRF/Chem modeling Study. Atmos. Environ., 43(4), 851-859, 2009.

Zhang, M., Uno, I., Zhang, R., Han, Z., Wang, Z., and Pu, Y.: Evaluation of the Models-3 Community Multi-scale Air Quality (CMAQ) modelling system with observations obtained during the TRACE-P experiment: Comparison of ozone and its related species, Atmos. Environ., 40(26), 4874-4882, 2006.

Zhang, Q., Streets, D. G., Carmichael, G. R., He, K. B., Huo, H., Kannari, A., Klimont, Z., Park, I. S., Reddy, S., Fu, J. S., Chen, D., Duan, L., Lei, Y., Wang, L. T., and Yao, Z. L.: Asian emissions in 2006 for the NASA INTEX-B mission, Atmos. Chem. Phys., 9, 5131-5153, doi:10.5194/acp-9-5131-2009, 2009. 